Article

\title{
The Presence of Behavioral Traps in U.S. Airline Accidents: A Qualitative Analysis
}

\author{
Jonathan Velazquez
}

School of Aeronautics, Inter American University of Puerto Rico, Bayamon Campus, Bayamon 00953, Puerto Rico; jvelazquez@bayamon.inter.edu; Tel.: +787-279-1912 (ext. 2416)

Received: 12 April 2017; Accepted: 9 January 2018; Published: 11 January 2018

\begin{abstract}
Behavioral traps are accident-inducing operational pitfalls aviators may encounter as a result of poor decision making. The Federal Aviation Administration (FAA) identifies the existence of twelve of these negative pilot behaviors. These are: Peer Pressure; Get-There-Itis; Loss of Situational Awareness; Descent Below the Minimum En Route Altitude (MEA); Mind Set; Duck-Under Syndrome; Getting Behind the Aircraft; Continuing Visual Flight Rules (VFR) into Instrument Conditions; Scud Running; Operating Without Adequate Fuel Reserves; Flying Outside the Envelope; and Neglect of Flight Planning, Preflight Inspections, and Checklists. The purpose of this paper was to study the nature of their occurrence in the airline domain. Four Subject Matter Experts (SMEs) analyzed 34 National Transportation Safety Board (NTSB) accident reports. The SMEs were able to identify many pilot actions that were representative of the behavioral traps. Behavioral traps were found in all accidents with Loss of Situational Awareness and Neglect of Flight Planning, Preflight Inspections, and Checklists dominant. Various themes began to emerge, which played important roles in many accidents. These themes included Crew Resource Management (CRM) issues, airline management and fatigue. The findings of this study indicated that behavioral traps were prevalent in airline accidents including habitual noncompliance by pilots. Attitude management training is recommended.
\end{abstract}

Keywords: behavioral traps; hazardous attitudes; cognitive biases; pilot error; attitude management

\section{Introduction}

Three out of four aviation accidents result from human error [1]. Behavioral traps are operational pitfalls aviators fall prey to as a result of bad decision making and inappropriate conduct. Many Aviation Safety Reporting System (ASRS) reports include a statement on the lessons learned after an aviation incident. The following are examples of some of those pilot testimonials that illustrate the presence of behavioral traps:

- Aircraft are machines subject to malfunction and we pilots who operate them are humans subject to human error. As a pilot who plans on remaining on the line, I have learned a valuable lesson-monitor the auto-flight system like a hawk.

- I was making a rushed approach to land. I have learned that when I am rushed is when I really need to take the time for the checklist.

- We thought we had a pretty good handle on our fuel state. Another minute or two of fuel and we would have made it safely to the airfield.

- I blame the mistake on simple overconfidence. Experience, it seems, is no replacement for doing one's homework.

Behavioral traps affect aviation flight safety. Even pilots with a considerable amount of experience may fall prey to them and are more likely to accept flights with greater risks, use less available cockpit resources and, in general, are more prone to bad decisions. 
The following section defines behavioral traps, hazardous attitudes and cognitive biases. This explanation is preceded by the hazardous attitudes. Similar to cognitive biases and behavioral traps in that they also affect decision making, hazardous attitudes are first introduced to the novice pilot before learning behavioral traps. Finally, because the very presence of these unsafe behaviors is caused by a breakdown of team dynamics in the cockpit, a brief discussion of Crew Resource Management (CRM) is included.

\subsection{Defining Behavioral Traps and Other Decision Making Fallibilities}

Unsafe pilot behaviors have been part of the FAA literature since the foundations of Aeronautical Decision Making (ADM) [2]. ADM is defined by the FAA [2] as a "systematic approach to the mental process used by pilots to consistently determine the best course of action for a given set of circumstances." For many future pilots, the concept of hazardous attitudes is their first exposure to the factors that affect decision making and judgment. Table 1 describes the five hazardous attitudes and provides the recommended antidote to counteract the thought. Before discussing behavioral traps, it is appropriate to take a look at the five classical hazardous attitudes, which have received more attention by scholars and the FAA. Similar to the behavioral traps, these attitudes also affect decision making: Macho, Anti-authority, Impulsivity, Resignation, and Invulnerability [3]. These attitudes go hand-in-hand with the twelve behavioral traps described in the FAA's [1] Risk Management Handbook.

Table 1. Overview of hazardous attitudes with the appropriate antidote [3].

\begin{tabular}{cll}
\hline $\begin{array}{c}\text { Hazardous } \\
\text { Attitude }\end{array}$ & \multicolumn{1}{c}{ Characteristics } & \multicolumn{1}{c}{ Antidote } \\
\hline Anti-authority & $\begin{array}{l}\text { Pilots with this attitude dislike following the rules or having } \\
\text { someone else tell them what to do. To these pilots, rules and } \\
\text { procedures are a waste of time and effort. }\end{array}$ & $\begin{array}{c}\text { "Follow the rules; they are } \\
\text { usually right." }\end{array}$ \\
\hline Impulsivity & $\begin{array}{l}\text { This attitude belongs to pilots who feel they must do } \\
\text { something, anything, and immediately. They seldom take a } \\
\text { moment to reflect or evaluate all the possibilities. Their actions } \\
\text { are the result of whatever comes first to mind. }\end{array}$ & "Not so fast; think first." \\
\hline Macho & $\begin{array}{l}\text { Macho pilots are risk takers, people overconfident about their } \\
\text { skills and constantly proving that they are better than } \\
\text { everybody else. To them, they are the best pilots out there. }\end{array}$ & "Taking chances is \\
Invulnerability & $\begin{array}{l}\text { Similar to macho-type pilots, these pilots also take risks but } \\
\text { only because in their mind accidents happen to others and not } \\
\text { to them. They are untouchable. }\end{array}$ & "It could happen to me." \\
\hline \multirow{2}{*}{ Resignation } & $\begin{array}{l}\text { People with this attitude feel they are incapable of making a } \\
\text { difference. Pilots with resignation-type attitudes are passive } \\
\text { and inactive throughout their flights. To these pilots, when } \\
\text { something bad happens it is due to bad luck or the fault of } \\
\text { others; someone else is responsible. }\end{array}$ & "I am not helpless; I can \\
\hline
\end{tabular}

The hazardous attitudes share commonalities with the behavioral traps. Refer to Table 2 for a summary of the behavioral traps as defined by the FAA. It is likely that at some point in their careers, veteran aviators may have fallen prey to, or have been tempted by, one or more of these tendencies in their flying professions [1].

As indicated earlier, behavioral traps and hazardous attitudes share some commonalities. For example, an individual experiencing Anti-authority could fall under the behavioral trap of Duck-Under Syndrome or Neglect of Flight Planning, Preflight Inspections, and Checklists. An aviator exhibiting Macho might experience the behavioral trap known as Flying Outside the Envelope. Scud Running and Operating Without Adequate Fuel Reserves are indicative of the hazardous attitude known as Invulnerability. The behavioral traps known as Mind Set and Get-There-Itis are signs of a 
pilot affected by Impulsivity. Lastly, Getting Behind the Aircraft and Peer Pressure both characterize pilots with the hazardous attitude identified as Resignation.

Table 2. Overview of behavioral traps as defined by the FAA [4].

\begin{tabular}{|c|c|}
\hline Behavioral Trap & Definition \\
\hline Peer Pressure & $\begin{array}{l}\text { Poor decision-making may be based upon an emotional response to peers, rather } \\
\text { than evaluating a situation objectively. }\end{array}$ \\
\hline Mind Set & $\begin{array}{l}\text { A pilot displays Mind Set through an inability to recognize and cope with changes } \\
\text { in a given situation. }\end{array}$ \\
\hline Get-There-Itis & $\begin{array}{l}\text { This disposition impairs pilot judgment through a fixation on the original goal or } \\
\text { destination, combined with a disregard for any alternative course of action. }\end{array}$ \\
\hline Duck-Under Syndrome & $\begin{array}{l}\text { A pilot may be tempted to make it into an airport by descending below minimums } \\
\text { during an approach. A pilot may believe that there is a built-in margin of error in } \\
\text { every approach procedure, or a pilot may not want to admit that the landing } \\
\text { cannot be completed and a missed approach must be initiated. }\end{array}$ \\
\hline Scud Running & $\begin{array}{l}\text { This occurs when a pilot tries to maintain visual contact with the terrain at low } \\
\text { altitudes while instrument conditions exist. }\end{array}$ \\
\hline $\begin{array}{l}\text { Continuing Visual Flight } \\
\text { Rules (VFR) into } \\
\text { Instrument Conditions }\end{array}$ & $\begin{array}{l}\text { Spatial disorientation or collision with ground/obstacles may occur when a pilot } \\
\text { continues VFR into instrument conditions. This can be even more dangerous if the } \\
\text { pilot is not instrument rated or current. }\end{array}$ \\
\hline Getting Behind the Aircraft & $\begin{array}{l}\text { This pitfall can be caused by allowing events or the situation to control pilot actions. } \\
\text { A constant state of surprise at what happens next may be exhibited when the pilot } \\
\text { is Getting Behind the Aircraft. }\end{array}$ \\
\hline $\begin{array}{l}\text { Loss of } \\
\text { Positional/Situational } \\
\text { Awareness }\end{array}$ & $\begin{array}{l}\text { In extreme cases, when a pilot gets behind the aircraft, a loss of positional or } \\
\text { situational awareness may result. The pilot may not know the aircraft's } \\
\text { geographical location or may be unable to recognize deteriorating circumstances. }\end{array}$ \\
\hline $\begin{array}{l}\text { Operating Without } \\
\text { Adequate Fuel Reserves }\end{array}$ & $\begin{array}{l}\text { Ignoring minimum fuel reserve requirements is generally the result of } \\
\text { overconfidence, lack of flight planning, or disregarding applicable regulations. }\end{array}$ \\
\hline $\begin{array}{l}\text { Descent Below the } \\
\text { Minimum En Route } \\
\text { Altitude (MEA) }\end{array}$ & $\begin{array}{l}\text { The Duck-Under Syndrome, as mentioned above, can also occur during the en } \\
\text { route portion of an Instrument Flight Rules (IFR) flight. }\end{array}$ \\
\hline $\begin{array}{l}\text { Flying Outside the } \\
\text { Envelope }\end{array}$ & $\begin{array}{l}\text { The assumed high-performance capability of a particular aircraft may cause a } \\
\text { mistaken belief that it can meet the demands imposed by a pilot's overestimated } \\
\text { flying skills. }\end{array}$ \\
\hline $\begin{array}{l}\text { Neglect of Flight Planning, } \\
\text { Preflight Inspections, and } \\
\text { Checklists }\end{array}$ & $\begin{array}{l}\text { A pilot may rely on short- and long-term memory, regular flying skills, and familiar } \\
\text { routes instead of established procedures and published checklists. This can be } \\
\text { particularly true of experienced pilots. }\end{array}$ \\
\hline
\end{tabular}

Cognitive biases can also distort decision making and lead to an aviation disaster [5]. There are certain pilot cognitive biases that may affect the safety of flight. Dismukes, Berman and Loukopoulos [6] analyzed 19 major U.S. accidents between 1991 and 2000 in which the NTSB identified crew error as a causal factor. Various common cognitive bias themes emerged from this study; nine accidents were the result of, or influenced by, plan continuation bias, a tendency to remain fixed on the pre-determined course of action or destination. They [6] also noticed that crews succumbed to increasing workload and were unable to perform tasks well once the flight demands intensified. This could be related to confirmation bias, a tendency to focus on information that confirms our beliefs when too much information is available. Finally, four out of the 19 accidents showed that pilots deviated from explicit guidance or SOPs. The pilot cognitive biases and operational errors found during this [6] study resemble the FAA behavioral traps. 


\subsection{Crew Resource Management and Behavioral Traps}

CRM is an FAA-mandated professional training provided by air carriers to assist captains and first officers in their use of all resources (e.g., human, hardware and software). CRM is the epitome or ultimate expression of teamwork between flight crewmembers prior, during and after a flight. Good CRM practices are predicated on following checklists, Standard Operating Procedures (SOPs), conducting good preflight action, maintaining open communication and engaging in proper flight planning to prepare for unexpected events during flight. Initially, the concept was known as cockpit resource management; however, CRM programs evolved to include flight attendants, maintenance personnel, dispatchers and others [7]. The current definition includes all groups routinely working together with the flight crew who are involved in the decision making processes required for the safe operation of the flight.

CRM training is one way to address the challenge of improving the human/machine relationship — by using checklists, resources and written procedures—and accompanying interpersonal activities [1]. Advisory Circular 120-51e [8] is the official FAA manuscript that provides guidance to air carriers on implementing CRM training. The major topics within a typical CRM training program are: (a) communications processes; (b) decision behaviors; (c) team building and maintenance; (d) workload management; (e) and situation awareness. Unfortunately, the FAA does not provide specific guidelines towards attitude management training, nor does it provide much information to counteract the hazardous attitudes, behavioral traps or the various cognitive biases pilots are usually confronted with. Attitude management is defined by the FAA [1] as "the ability to recognize hazardous attitudes in oneself and the willingness to modify them as necessary through the application of an appropriate antidote thought."

The most recent generation of CRM focused on Threat and Error Management (TEM) [9]. During TEM, aircrews apply risk management strategies to avoid, trap, and mitigate errors [10]. However, for pilots, recognizing self-attitudes or personality threats that are hazardous to flight safety is not easy, albeit a necessary task during CRM.

\subsection{Aims and Objectives}

This research sought to reveal the presence of behavioral traps in the U.S. Title 14 of the Code of Federal Regulations (CFR) Part 121 airline domain. The study led to a greater understanding of how behavioral traps affect team dynamics in the cockpit and a specific understanding of how behavioral traps affect aeronautical decision making and ultimately flight safety. In addition, knowledge of these behavioral traps in crews can influence portions of CRM training to include hazardous behavior identification and modification techniques.

Several studies [6] have suggested the presence of many unsafe pilot attitudes during airplane accidents that impair judgment. However, no published study had examined the presence of behavioral traps within crew operated flights. Instead, studies concerning unsafe pilot behavior have been mostly limited to the single-pilot and/or the General Aviation (GA) domain. Whether it is behavioral traps or other decision making imperfections (e.g., hazardous attitudes, cognitive biases), it is important to continue to explore the limitations of human performance so that appropriate safety interventions may be revised (i.e., CRM) or, if necessary, devised anew.

\section{Materials and Methods}

This study utilized archival research methods to explore the behavioral traps contributing to flight crew accidents. This research drew from the population of 34 NTSB U.S. Aviation Accident Reports (AARs) and factual reports attributed to flight crew error from 1991 to 2013. The reports were used to explore exclusively commercial Part 121 flight crew-related accidents. Purposive, also known as judgmental, sampling was used to study only those NTSB accident reports where flight crew error was a causal factor. 
There are various reasons for selecting the time frame specified. First, beyond 1991, the NTSB has consistently generated factual reports in its analysis of aviation accidents. Second, the years 1991 to 2013 were selected because the vast majority of the factual reports had already been upgraded from preliminary to final status. The accident reports were downloaded from Embry-Riddle Aeronautical University's website collection of NTSB AARs. Third, beginning in 1991, CRM training had been established successfully at most U.S. airlines and was maturing [9]. An analysis of behavioral traps during this period, albeit to a very limited degree, (indirectly) highlighted successes or shortcomings with such a training program.

\subsection{Sources of Data}

The data collected from the NTSB had to conform to the following criteria: U.S. 14 CFR Part 121 airline accidents that were partly or wholly attributed to flight crew error. In addition, the accident must have involved death, serious injury or substantial damage to the aircraft. Excluded from consideration were accidents with undetermined causes and those that were attributed to sabotage, suicide or criminal activity such as hijacking. Accidents attributed to maintenance issues are only included if improper crew decisions contributed to the accident.

\subsection{Data Collection}

A team composed of four Certified Flight Instructors (CFIs) served as Subject Matter Experts (SMEs) and coded the data. Furthermore, these SMEs also had an Airline Transport Pilot (ATP) certificate. The possession of a flight instructor certificate and an ATP certificate ensured that all SMEs have (1) been exposed to commercial operations and (2) taught the concepts of hazardous attitudes and behavioral traps to students. All SMEs became thoroughly familiar with the behavioral traps by receiving the necessary instruction on these unsafe pilot behaviors before the data were coded and analyzed. Familiarization training and evaluation sessions included case studies with examples of behavioral trap categorization techniques. After training, the aircraft accidents were randomly assigned to the SMEs such that at least two different SMEs independently analyzed each accident.

The SMEs used a subset of the FAA-defined list of behavioral traps (see Table 2) to classify the unsafe pilot behaviors. In the past, Jeppesen [11] had categorized the list of behavioral traps among: (1) General Aviation (GA); (2) instrument-rated; and (3) commercial pilots. Because U.S. Part 121 airline flights are conducted under Instrument Flight Rules (IFR), this study used the commercial and instrument behavioral traps. For ease of understanding and because of the similarities in their definitions, the behavioral traps of Descent Below the Minimum En Route Altitude (MEA) and Duck-Under Syndrome were merged into a new one called Unauthorized Descent Below an IFR Altitude. Likewise, this study will follow the Jeppesen [11] recommendation to combine the behavioral traps of Loss of Positional/Situational Awareness with Getting Behind the Aircraft. This combination resulted in the behavioral trap called Loss of Situational Awareness. In summary, the following list of behavioral traps was studied: (1) Peer Pressure; (2) Get-There-Itis; (3) Unauthorized Descent Below an IFR Altitude; (4) Loss of Situational Awareness; and (5) Neglect of Flight Planning, Preflight Inspections, and Checklists. Having said this, the SMEs were alerted to lookout for the presence of other GA or VFR behavioral traps such as Flying Outside the Envelope. Table 3 illustrates the behavioral traps under consideration.

Using the narrative data obtained from the NTSB as the first step in the analysis, the SMEs used the AARs and Factual Reports to assemble a chain of events for each accident. It was necessary for both SMEs to agree on what constituted an event, the sequence of events, the pilot actions associated with those events and how the events affected decision making and CRM. Next, the SMEs examined the reports for evidence of pilot actions related to behavioral traps. Again, both SMEs had to agree on what constituted a pilot action and if that action was reflective of a behavioral trap. Any incongruities among the SMEs were dealt with through integrative sessions. These sessions allowed ideas and notes 
to be cross-compared with the other SME that shared the same NTSB report. This final act led to new observations and/or linkages, which resulted in revisions in the data collection process.

Table 3. Justification for inclusion or exclusion of behavioral traps for this study. GA, General Aviation.

\begin{tabular}{|c|c|}
\hline Behavioral Trap & Determination \\
\hline Peer Pressure & $\begin{array}{l}\text { One of the commercial behavioral traps according to Jeppesen [11]. Therefore, it was } \\
\text { included in this study }\end{array}$ \\
\hline Mind Set & $\begin{array}{l}\text { One of the VFR or GA behavioral traps according to Jeppesen [11]. Therefore, it was } \\
\text { not included in this study. }\end{array}$ \\
\hline Get-There-Itis & $\begin{array}{l}\text { One of the commercial behavioral traps according to Jeppesen [11]. Therefore, it was } \\
\text { included in this study }\end{array}$ \\
\hline Duck-Under Syndrome & $\begin{array}{l}\text { One of the instrument behavioral traps according to Jeppesen [11]. Because Part } 121 \\
\text { operations are conducted under IFR, it was included in this study. However, this } \\
\text { concept was merged with Descent Below the Minimum En Route Altitude (see below) } \\
\text { into a new behavioral trap called: Unauthorized Descent Below an IFR Altitude. }\end{array}$ \\
\hline Seud Running & $\begin{array}{l}\text { One of the VFR or GA behavioral traps according to Jeppesen [11]. Therefore, it was } \\
\text { not included in this study. }\end{array}$ \\
\hline $\begin{array}{l}\text { Eontinuing Visual Flight } \\
\text { Rules (VFR) inte } \\
\text { Instrument Conditions }\end{array}$ & $\begin{array}{l}\text { One of the VFR or GA behavioral traps according to Jeppesen [11]. Therefore, it was } \\
\text { not included in this study. }\end{array}$ \\
\hline $\begin{array}{l}\text { Getting Behind the } \\
\text { Aircraft }\end{array}$ & $\begin{array}{l}\text { Jeppesen merged this commercial behavioral trap with Loss of Situational Awareness } \\
\text { (see below) and for good reason. The FAA [1] explains that, in extreme cases, when a } \\
\text { pilot gets behind the aircraft, a loss of positional or situational awareness may result. }\end{array}$ \\
\hline $\begin{array}{l}\text { Loss of } \\
\text { Positional/Situational } \\
\text { Awareness }\end{array}$ & $\begin{array}{l}\text { One of the commercial behavioral traps according to Jeppesen [11]. Therefore, it is } \\
\text { included in this study }\end{array}$ \\
\hline $\begin{array}{l}\text { Operating Without } \\
\text { Adequate Fuel Reserves }\end{array}$ & $\begin{array}{l}\text { One of the VFR or GA behavioral traps according to Jeppesen [11]. Therefore, it was } \\
\text { not included in this study. }\end{array}$ \\
\hline $\begin{array}{l}\text { Descent Below the } \\
\text { Minimum En Route } \\
\text { Altitude }\end{array}$ & $\begin{array}{l}\text { One of the instrument behavioral traps according to Jeppesen [11]. Because Part } 121 \\
\text { operations are conducted under IFR, it is included in this study. However, this trap } \\
\text { has been merged with Duck-Under Syndrome (see above) into a new behavioral trap } \\
\text { called: Unauthorized Descent Below and IFR Altitude. }\end{array}$ \\
\hline $\begin{array}{l}\text { Flying Outside the } \\
\text { Envelope }\end{array}$ & $\begin{array}{l}\text { One of the VFR or GA behavioral traps according to Jeppesen [11]. Therefore, it was } \\
\text { not included in this study. }\end{array}$ \\
\hline $\begin{array}{l}\text { Neglect of Flight } \\
\text { Planning, Preflight } \\
\text { Inspections, and } \\
\text { Checklists }\end{array}$ & $\begin{array}{l}\text { One of the commercial behavioral traps according to Jeppesen [11]. Therefore, it was } \\
\text { included in this study }\end{array}$ \\
\hline
\end{tabular}

The goal of this research project was to discover what behavioral traps may exist in the Part 121 accident world and how they manifest. Although the behavioral traps were used as a priori codes, the coding process of the SMEs included the thorough review of each NTSB report for key text identifying operational errors that led to the behavioral traps themselves. The NTSB reports were independently coded and subsequently cross-checked to develop consistency in coding (inter-rater consensus). The coded text passages within the NTSB document, although done manually by the pilot experts, was subsequently entered into a qualitative data analysis software called QSR NVivo.

\subsection{Treatment of the Data}

The treatment of the data included descriptive statistics demonstrating the prevalence of each behavioral trap across the aviation accidents and the most prominent contributing factors, as well. However, with NVivo, the data transitioned beyond descriptions of the coded text to an analysis of associations, comparisons and pattern identifications. Comparing and contrasting the data may 
reveal systems, relationships and processes that could not be discovered in the manual coding stage. When investigating relational patterns, the researchers explore specific connections between pairs of codes in the data, some by building a data narrative and others by examining relationships between categories within the data [12].

\subsection{Reliability and Validity of the Data}

To assess the quality of the qualitative portion of a study, researchers may employ four tests named: credibility, dependability, transferability and compatibility [13]. Some of these tests were more applicable to this archival design than others.

Credibility refers to accuracy; the descriptions of the events or aviation accidents and antecedents must be plausible and recognizable. Credibility was achieved by including other investigators in the study, namely the SMEs.

Dependability is more suited to interviews or observational research and refers to the extent to which another researcher, with similar training and rapport with participants, makes the same observations. Although not entirely applicable to archival studies, the SMEs still cross-checked their coding process against each other and, in similar fashion, gained dependability.

Transferability refers to the generalizability of the study findings to other settings, populations and context. This test of quality is usually one weakness of studies involving qualitative methods; however, sufficient details regarding methodology procedures allow readers to assess this. Transferability is akin to external validity. The interpretations and conclusions of this study could be applicable to most U.S. air carrier environments, resulting in good external validity [14].

Finally, confirmability refers to the objectivity of the data or how much another researcher agrees with the meaning of the data. This was achieved by three methods: (1) a team (all SMEs) coded and categorized the narratives of the NTSB reports; (2) the SMEs had a coding scheme from which to work (i.e., the subset of FAA list of behavioral traps); and (3) inter-coder consensus: the SMEs reconciled any differences found during the coding process by comparing their work against each other.

The behavioral traps are well-defined and well-known FAA terms. The NTSB accident reports offered an accessible account that included facts, findings of causal factors and recommendations. The focus of this research was on the human (pilot) experience as recorded by the NTSB accounts; the archives provided deep insights that were not possible with quantitative methods. The SMEs all had similar backgrounds as professional pilots and flight instructors and were exposed, through flight experience and professional training, to the concepts of unsafe behaviors by pilots.

\section{Results}

\subsection{Descriptive Statistics}

As described in the previous section, for each case, the assigned SMEs determined which behavioral traps were present. Every SME found a minimum of one behavioral trap and a maximum of four throughout the analysis. The average number of behavioral traps was two with a standard deviation of 0.60 . In addition, during the coding process, the researcher asked the SMEs to identify actions representative of the behavioral traps and any contributing factors that may have influenced the outcome of the flight. Figure 1 shows the frequency with which the behavioral traps were present in all the aviation accidents. Figure 2 displays the most prevalent traps in fatal accidents. Please use the following descriptors for understanding: LSA = Loss of Situational Awareness, Neg = Neglect of Flight Planning, Preflight Inspections, and Checklists, PP = Peer Pressure, Get $=$ Get-There-Itis, Des $=$ Unauthorized Descent Below an IFR Altitude .

The behavioral traps of Loss of Situational Awareness and Neglect of Flight Planning, Preflight Inspections, and Checklists were overwhelmingly dominant, even throughout the fatal accidents. Peer Pressure, Get-There-Itis and Descent Below an IFR Altitude were each found in six accident reports 
or fewer. The prominence of Loss of Situational Awareness in fatal accidents is unsurprising given that it has been well established that situational awareness is often implicated in aviation accidents.

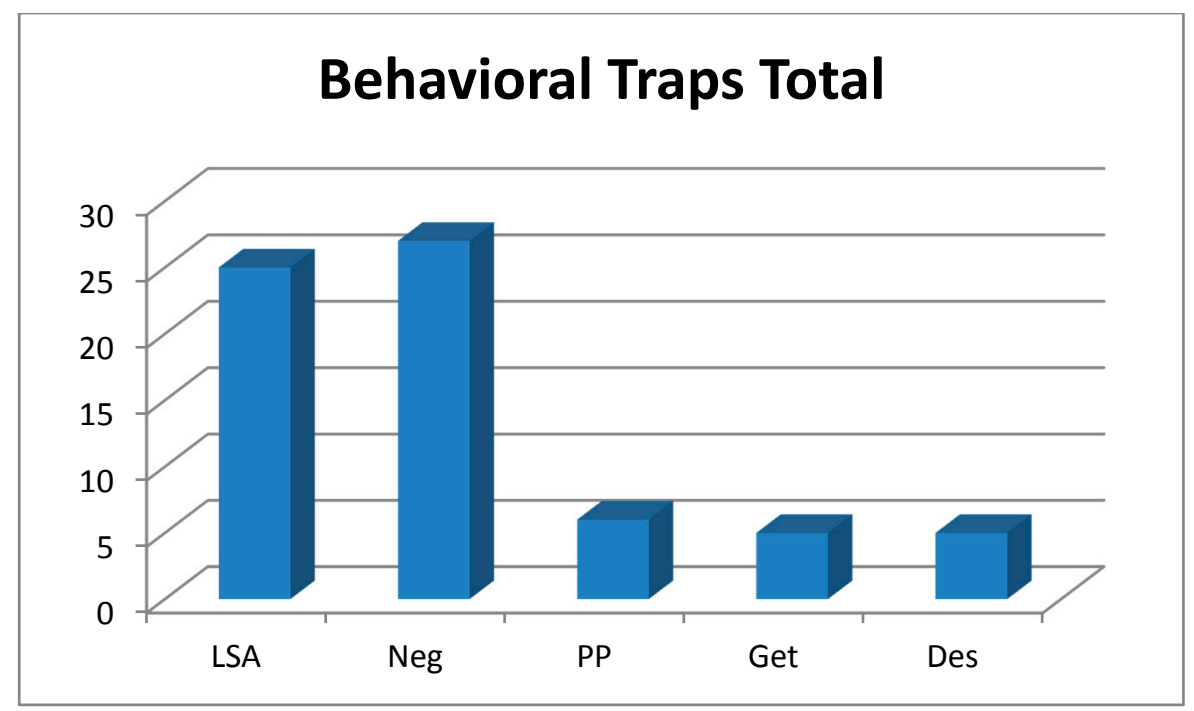

Figure 1. Frequency count of all behavioral traps found. LSA = Loss of Situational Awareness, Neg = Neglect of Flight Planning, Preflight Inspections, and Checklists, PP = Peer Pressure, Get $=$ Get-There-Itis, Des $=$ Unauthorized Descent Below an IFR Altitude.

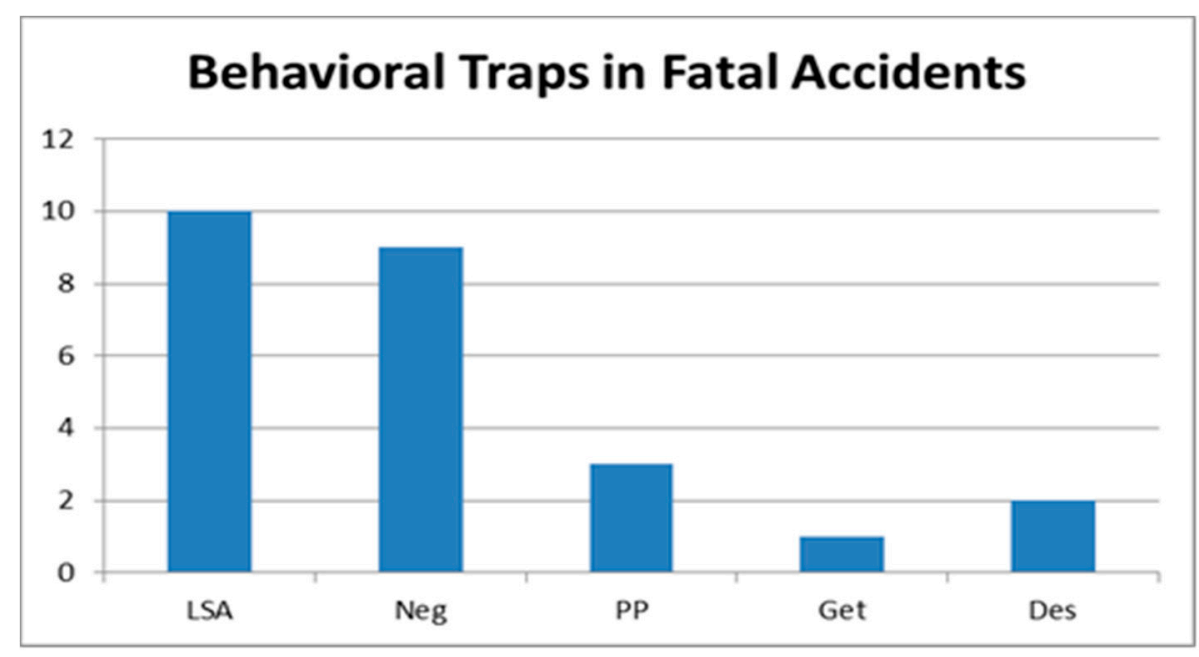

Figure 2. Behavioral traps in fatal accidents only.

Aviation accidents are generally the result of a series of simultaneous or consecutive circumstances that each add operational risk; seldom is a single isolated cause identified. During the analysis of the coding process performed by the SMEs, various themes began to emerge, which played significant roles in many accidents. These topics were airline management, CRM issues, fatigue and a former behavioral trap called Flying Outside the Envelope. This latter trap was left out of the current study due to Jeppesen's [11] categorization of the behavioral traps among commercial, instrument-rated and general aviation pilots. However, during training, the SMEs were alerted to the existence of all behavioral traps and were told to flag them if they saw their presence among Part 121 pilots. Figure 3 shows the distribution of these contributory factors. For ease of understanding, please observe the following: Airline $=$ airline management issues, $C R M$ issues $=$ lack or poor practice of Crew Resource Management, Envelope = the behavioral trap called Flying Outside the Envelope and Fatigue $=$ accidents where fatigue was a contributing factor. 


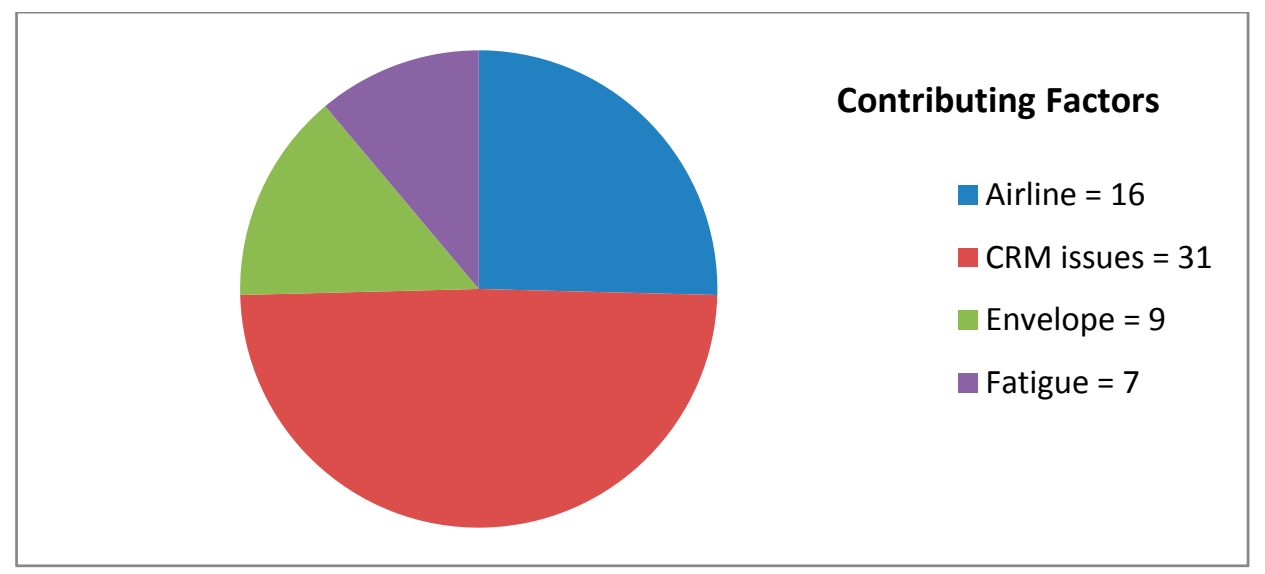

Figure 3. Other contributing factors in connection with the Part 121 accidents. CRM, Crew Resource Management.

\subsection{Qualitative Data}

The following section describes, in comprehensive fashion, how each unsafe behavior is manifested within pilots of the aviation accidents. For the sake of avoiding the repetition of similar pilot actions, only the most representative examples (i.e., NTSB report passages) are illustrated for the top two behavioral traps found, as well as for the remaining traps of Peer Pressure, Unauthorized Descent Below an IFR Altitude and Get-There-Itis. Because an unexpected trap had a presence in Part 121 accidents, results are also shown for the additional behavioral trap of Flying Outside the Envelope. The pilot actions representative of the behavioral traps are illustrated using tables that are immediately followed by word frequency queries called tags or word clouds.

A tag or word cloud is a visual representation of textual data highlighting the importance of the most commonly-used words within a source (e.g., document, interview). Each cloud shows the most frequently-used words by increasing its font size and placing those words nearer the center of the cloud. Word or tag clouds are very useful for quickly perceiving the most prominent term and its relative prominence compared to others used within a source. The relative font size indicates which words were coded most commonly throughout the sources. This last action was performed to investigate common or emerging themes within the traps themselves and the contributory factors that arose when the SMEs began to analyze the data.

\subsection{The Top Behavioral Traps}

Neglect of Flight Planning, Preflight Inspections, and Checklists was found in 27 (79\%) of 34 cases. A closer examination of this behavioral trap reveals that more than one action is being accounted for. Any occasion where the pilot would deliberately or unconsciously bypass a procedure, checklist, inspection or flight planning process, the SME team would code this behavior under this node within NVivo. Table 4 lists illustrations of pilot actions that exemplify Neglect of Flight Planning, Preflight Inspections, and Checklists found in the aviation accidents.

Figure 4 shows a frequency query tag cloud illustrating the prominence of specific words within the sources analyzed: NTSB AARs and NTSB factual reports. The most frequently-used words for this behavioral trap were captain, airplane, procedures, approach and checklist. Because this behavioral trap takes more than one action into consideration, the most frequently-used words align well with the concept or behavioral trap itself. The word captain might signal that he/she is the flight crewmember that is initiating or prompting the behavioral trap. The word airplane might be used in connection to airplane procedures or airplane checklists, which are also top words found in the query. Finally, the inclusion of the word approach might suggest that it is during the approach and landing phase where most of the manifestations of this trap are occurring. 
Table 4. Examples of Neglect of Flight Planning, Preflight Inspections, and Checklists.

\begin{tabular}{|c|c|}
\hline Accident Report & Examples \\
\hline 00-02 & $\begin{array}{l}\text { Although the airplane speed was within the target range, the airplane did not meet } \\
\text { FedEx's criteria for a stabilized approach because its rate of descent was greater than } \\
\text { FedEx's recommended } 1000 \text { feet per minute (fpm). }\end{array}$ \\
\hline 09-03 & $\begin{array}{l}\text { Investigation revealed that the flight crew did not perform several of the appropriate } \\
\text { checklists and interrupted an emergency fire-related checklist. }\end{array}$ \\
\hline $11-02$ & $\begin{array}{l}\text { Had the captain complied with standard operating procedures in response to the flap } \\
\text { anomaly, unstabilized approach, stick shaker, and terrain awareness and warning system } \\
\text { warning and initiated a go around maneuver, the accident likely would not have } \\
\text { occurred. }\end{array}$ \\
\hline $93-02$ & $\begin{array}{l}\text { The captain returned about } 10 \mathrm{~min} \text { after officer, and neither of them performed a walk } \\
\text { around inspection of the airplane, nor were they required to do so by USAir procedures. }\end{array}$ \\
\hline $97-01$ & $\begin{array}{l}\text { He said that a "norm" existed for the first officer to make hydraulic system configuration } \\
\text { changes; he was aware that this was not standard operating practice, which assigned the } \\
\text { task to the pilot not flying at all times. He said he conducted his cockpit according to } \\
\text { standard operating practice, because he was new to the airplane, and he did not expect } \\
\text { first officers to configure the hydraulic pumps. }\end{array}$ \\
\hline 07-05 & $\begin{array}{l}\text { The abbreviated briefing was contrary to company policy, and the Safety Board notes } \\
\text { that it is prudent for pilots to fully conduct taxi briefings according to standard operating } \\
\text { procedures. }\end{array}$ \\
\hline 08-02 & $\begin{array}{l}\text { The first officer stated that he thought that pilots were required to (and should) check } \\
\text { landing distances with a contaminated runway. He said that he believed } 4000 \text { feet was } \\
\text { the required landing distance but indicated that they did not check the landing distance } \\
\text { charts. }\end{array}$ \\
\hline $10-01$ & $\begin{array}{l}\text { The reason the first officer retracted the flaps and suggested raising the gear could not be } \\
\text { determined from the available information, these actions were inconsistent with } \\
\text { company stall recovery procedures and training. }\end{array}$ \\
\hline $91-02$ & $\begin{array}{l}\text { "I'll just do a quick procedure turn headed back in, so I'm not going to straighten out on } \\
\text { the thing, the localizer, just teardrop and come right back around and land." The FO } \\
\text { [First Officer] simply responded "OK". }\end{array}$ \\
\hline $94-06$ & $\begin{array}{l}\text { The captain actively moved the power levers from the flight idle gate into the beta range } \\
\text { for undetermined reasons. Operation of the propellers in the beta range while in flight is } \\
\text { prohibited by the airplane flight manual. }\end{array}$ \\
\hline 06-01 & $\begin{array}{l}\text { About 1912:02, the captain transmitted a burp over the ARTCC [Air Route Traffic Control } \\
\text { Center] radio frequency that would have been heard by other pilots and air traffic } \\
\text { controllers. An unknown voice on the radio frequency responded to the captain's burp, } \\
\text { stating, "nice tone", and the [cockpit voice recorder] CVR recorded the accident pilot's } \\
\text { chuckling. About 1912:53, the captain talked about deliberately dropping a flight manual } \\
\text { on a passenger whose foot had intruded into the cockpit. The first officer engaged in } \\
\text { banter with the captain, and both pilots used informal, nonstandard terminology during } \\
\text { the flight. }\end{array}$ \\
\hline $96-07$ & $\begin{array}{l}\text { The captain was not authorized under the COM to allow the first officer to fly the } \\
\text { airplane. The captain told investigators that he was not familiar with the section of the } \\
\text { COM that indicated that he was not supposed to share flying duties with the first officer. }\end{array}$ \\
\hline
\end{tabular}

Peer Pressure was found in $6(18 \%)$ of 34 cases. Peers are important social components of life. However, friends, colleagues, and associates may cloud judgment. The desire to conform to others, to be accepted, and to be right are fundamental needs of human beings. Peer Pressure can be obvious or subtle, verbal or non-verbal, intentional or unintentional, and its origin may be personnel or organizational [15-20]. Peer Pressure is a behavioral trap that affects decision making. Table 5 lists illustrations of pilot actions that Peer Pressure. 


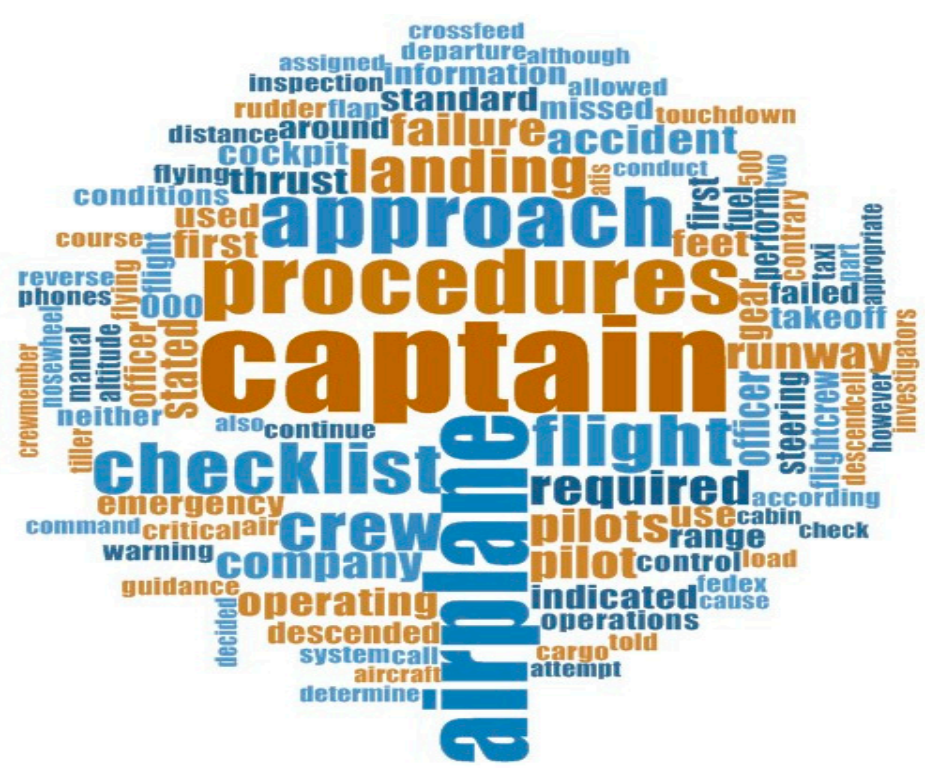

Figure 4. Tag cloud helps visualize the word query for Neglect of Flight Planning, Preflight Inspections, and Checklists.

Table 5. Examples of Peer Pressure.

\begin{tabular}{|c|c|}
\hline Accident Report & Examples \\
\hline $94-01$ & $\begin{array}{l}\text { Fifty feet, the first officer stated, "I'm gonna go around." The captain stated, "No, no, no I } \\
\text { got it" The first officer responded, "You got the airplane" As the first officer said the } \\
\text { world "airplane". The automatic voice said "thirty". The captain took control and landed } \\
\text { the airplane. }\end{array}$ \\
\hline $11-02$ & $\begin{array}{l}\text { Following the application of power, the airspeed began increasing. At 0435:40, the first } \\
\text { officer asked, "should I go around," and the captain replied, "no," and then stated, "keep } \\
\text { descending." }\end{array}$ \\
\hline $91-05$ & $\begin{array}{l}\text { The captain became overly reliant on the first officer. This contributed to the runway } \\
\text { incursion. The captain knew there was something wrong, he even questioned but } \\
\text { acknowledged the FO's instructions. }\end{array}$ \\
\hline 06-01 & $\begin{array}{l}\text { After hearing the weather observation, the captain commented, "we're not getting } \\
\text { in...we don't have an ILS [instrument landing system]." The first officer responded, "I } \\
\text { know...go all this [expletive] way. Well, let's try it." The captain responded, "yeah, we'll } \\
\text { try it." About } 30 \text { s later, the captain said, "I don't want to...go all the way out here for } \\
\text { nothing tonight," and moments later said, "I'll be so happy when we have an ILS } \\
\text { everywhere we go." The first officer concurred, and the captain continued, "I thought we } \\
\text { were gonna have it easy tonight." }\end{array}$ \\
\hline $97-01$ & $\begin{array}{l}\text { The first officer told Safety Board investigators that his goal after recognizing that the } \\
\text { flaps were not extended was to get the captain to initiate a go-around. Thirty seconds } \\
\text { before touchdown, the first officer stated "want to take it around?" and the captain } \\
\text { replied "no that's alright. * keep your speed up here about uh." When the captain denied } \\
\text { the first officer's request to go around and told him to keep his speed up, the first officer } \\
\text { did not challenge the captain's statement. He also did not question the captain to } \\
\text { determine his reason(s) for continuing the approach. The first officer stated that there } \\
\text { was no time for discussion with the captain because the approach was so fast. The first } \\
\text { officer's failure to question the captain's decision to continue the approach was } \\
\text { inconsistent with the CRM training he had received that emphasized the importance of } \\
\text { sharing doubts with other crewmembers and quickly resolving conflicts. }\end{array}$ \\
\hline $95-03$ & $\begin{array}{l}\text { During the course of performing the missed approach procedure, the first officer acted, } \\
\text { without challenge, to a command from the captain to "down, push it down." }\end{array}$ \\
\hline
\end{tabular}


Figure 5 shows a frequency query tag cloud illustrating the prominence of specific words within the sources analyzed. For Peer Pressure, the most frequently-coded words were captain, first, officer, stated and airplane. Once again, captain was one of the top words. As previously mentioned, the word captain might signal that he/she is the flight crewmember that is initiating or prompting the behavioral trap. However, captains might also be pressured by their first officer colleague. Because there is a relationship developing between these two crewmembers, it is not surprising that any instance of Peer Pressure will result in manifestations by the captain or first officer, hence the top two words found. The inclusion of the word stated must be due to the fact that any example of Peer Pressure begins or ends with a verbal statement by one of these flight crewmembers. The result is an action that changes the airplane's status; hence, the word airplane.

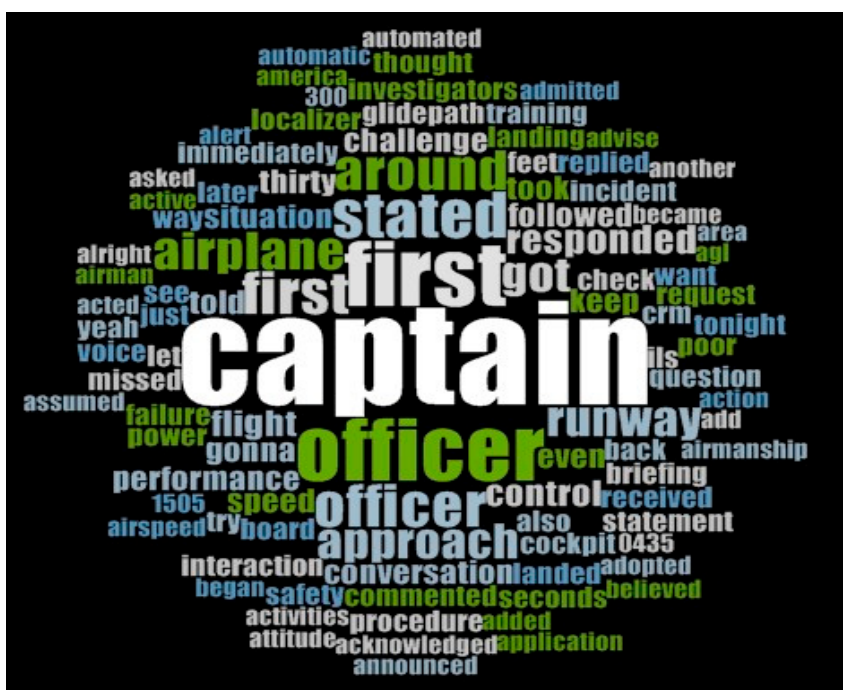

Figure 5. Tag cloud helps visualize word query for Peer Pressure.

Get-There-Itis is known in some textbooks and official FAA documents as Get-Home-Itis. During Get-There-Itis, the pilot's pressure comes from within (i.e., him/herself), and the obstinacy is specifically related to arriving at the destination. Table 6 lists the several illustrative instances of Get-There-Itis. This behavioral trap was found in five (15\%) of 34 cases.

Table 6. Examples of Get-There-Itis.

\begin{tabular}{cl}
\hline Accident Report & \multicolumn{1}{c}{ Examples } \\
\hline $01-02$ & $\begin{array}{l}\text { The cockpit voice recorder indicated that flight crew had discussed the weather and the } \\
\text { needed to expedite the Approach. The captain stated "we got to get over there quick." }\end{array}$ \\
\hline & $\begin{array}{l}\text { The pilots failed to conduct a prestart checklist properly and, subsequently, failed to } \\
\text { observe the illuminated light on the annunciator panel. A second opportunity to detect } \\
\text { the status of the pitot heat knob was the annunciator panel check just before takeoff. In } \\
\text { this case, the first officer called checklist items without the captain's request and without } \\
\text { using normal challenge and response procedures as the airplane was being taxied into } \\
\text { position for takeoff. The pilots appeared to be rushed, and there is no evidence that the } \\
\text { first officer actually observed the annunciator panel. }\end{array}$ \\
\hline $94-06$ & $\begin{array}{l}\text { The captain stated "man we're almost the speed of heat here, two sixty four or two sixty } \\
\text { three ... sixty two" he said "gosh, we gonna come down." }\end{array}$ \\
\hline 94-01 & $\begin{array}{l}\text { The flight crew ignored the present weather conditions and continued the approach to } \\
\text { land even during the unestablished approach, the Captain took the flight controls at the } \\
\text { last moment when it was too late to correct or execute a go around. }\end{array}$ \\
\hline 05-02 & $\begin{array}{l}\text { The Captain fixated on landing the airplane with a disregard for any alternative course } \\
\text { of action such as performing a go-around. }\end{array}$ \\
\hline
\end{tabular}


Passages such as "we got to get there over quick, the pilots appeared to [be] rushed, man we're almost the speed of heat here, crew ignored the present weather and continued the approach, and finally, the captain fixated on landing the airplane with disregard for any alternative course" are all signs of Get-there-Itis. Figure 6 shows that the most frequently-coded words for this behavioral trap were captain, flight, airplane, crew, approach, weather and landing. The stubbornness of reaching the destination airport at all costs, even if this means disregarding the weather conditions, by both crew members resulted in the inclusion of the words captain, weather and crew. It seems as it is during the approach and landing phase where this behavioral trap is most routinely manifested; hence, the words approach and landing.

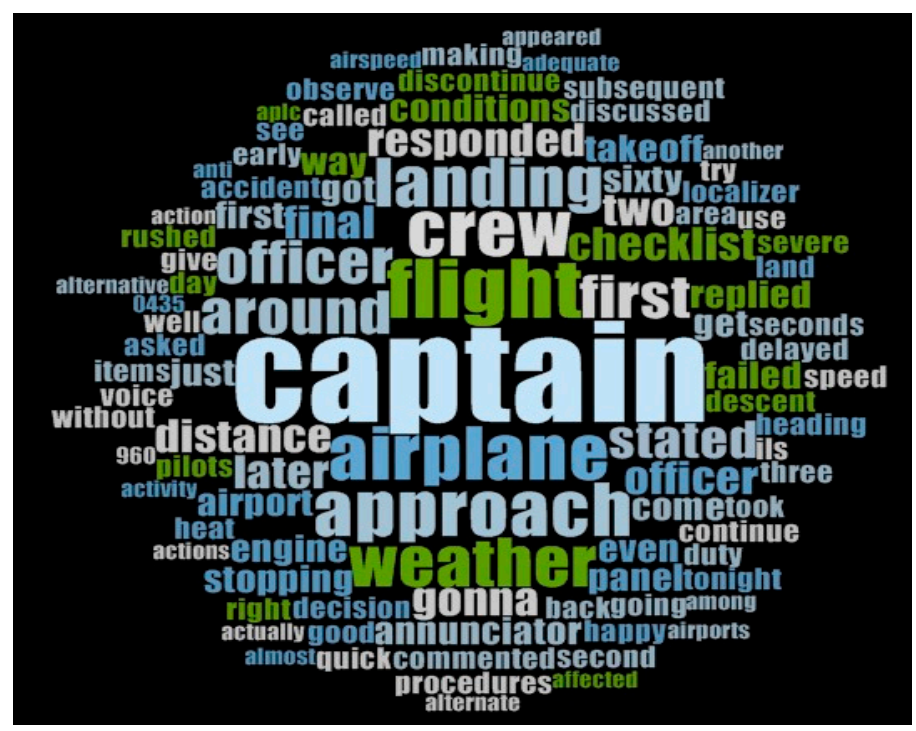

Figure 6. Word frequency tag cloud for Get-There-Itis.

Unauthorized Descent Below an IFR Altitude was found in five (15\%) of 34 reports. A combination of the previously-named behavioral traps Descent Below the MEA and Duck-Under Syndrome, the concept is evidenced when a pilot descends below minimum altitudes during the en route phase of flight or during the approach stage before obtaining visual contact with the environment, either due to a belief that there is a built-in margin of error in every approach procedure or a refusal to admit that the landing cannot be safely accomplished and a missed approach must be initiated. Table 7 highlights several illustrations of pilot actions that exemplify the behavioral trap known as Unauthorized Descent Below an IFR Altitude.

Table 7. Examples of Unauthorized Descent Below an IFR Altitude.

\begin{tabular}{cl}
\hline Accident Report & \multicolumn{1}{c}{ Examples } \\
\hline $14-02$ & $\begin{array}{l}\text { The airplane continued to descend at } 1500 \mathrm{fpm} \text { and passed through and continued below the } \\
\text { desired glidepath. }\end{array}$ \\
\hline 91-02 & $\begin{array}{l}\text { Captain descended below } 3000 \text { feet prior to establishing the airplane on final approach course, } \\
\text { contrary to directions on the approach plate and establish requirements [ ... ] captain did not } \\
\text { have the runway environment in sight when he told the first officer to continue the approach. }\end{array}$ \\
\hline 06-01 & $\begin{array}{l}\text { The captain, while acting as pilot flying, descended below the MDA [minimum descent altitude] } \\
\text { after supposedly having the approach lights in sight. The airplane struck trees and crashed just } \\
\text { short of the runway. }\end{array}$ \\
\hline 08-01 & $\begin{array}{l}\text { The MDA for the localizer (glideslope out) approach to runway 28 was 429 feet [above ground } \\
\text { level] agl. No CVR evidence or post-accident interview information indicated that either } \\
\text { crewmember had the runway environment in sight by that altitude. }\end{array}$ \\
\hline $96-05$ & $\begin{array}{l}\text { The captain initially did not recognize the descent below MDA, and he failed to react } \\
\text { immediately when he was alerted to the altitude deviation by the first officer. }\end{array}$ \\
\hline
\end{tabular}


Descending below the glide path, glideslope or minimum descent altitude (MDA) without establishing visual contact with the airport environment are all examples of Unauthorized Descent below an IFR Altitude. Figure 7 demonstrates the most frequently coded words within this behavioral trap. These words were airplane, MDA, approach, captain, descended and runway. Because the crew commands the airplane to an altitude that is dangerously low, it is not surprising to see the word airplane among the most frequently-found words. As with the previous behavioral traps, the word captain appears once again within the most common words. It is the captain that has the final authority as to the operation of the flight. The appearance of the word descended is no surprise considering that the nature of the trap itself is a descent below an altitude. Because the objective of the crew is to make visual contact with the runway or airport environment, it not surprising to see the word runway among the top words in this query. Finally, MDA stands for minimum descent altitude. This altitude was repeatedly descended through without adequate visual contact with the runway; hence, MDA as one of the most common words.

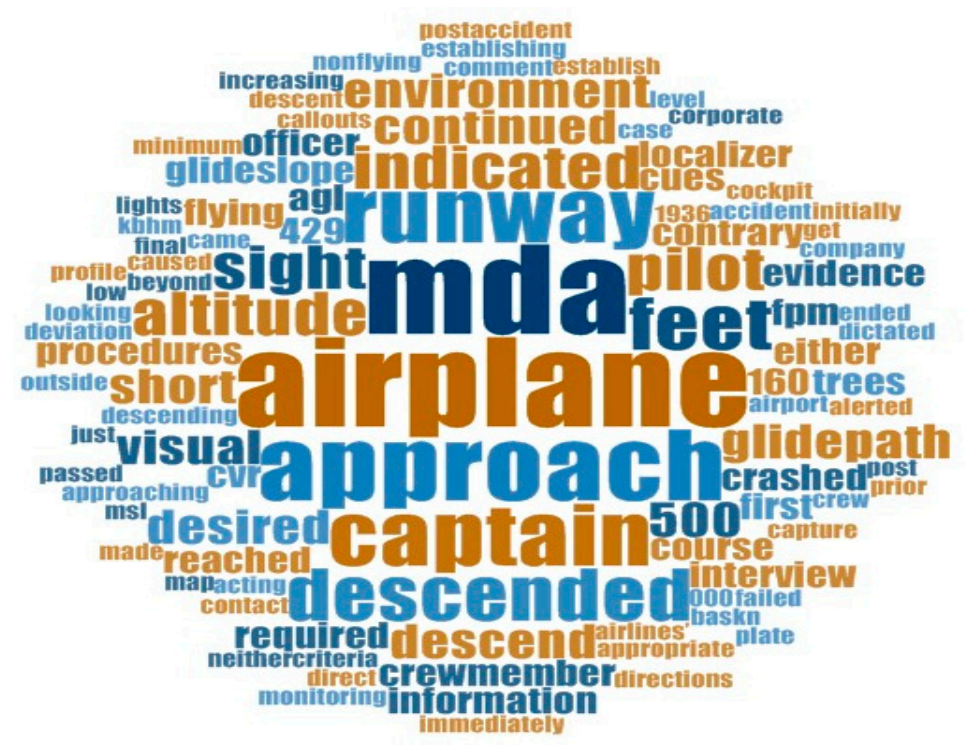

Figure 7. Word frequency tag cloud for Unauthorized Descent Below an IFR Altitude.

Loss of Situational Awareness was found in 25 (74\%) of 34 cases. The FAA [1] explains that, in extreme cases, when a pilot gets behind the aircraft, a loss of positional or situational awareness may result. The pilot may not know the aircraft's geographical location, or may be unable to recognize deteriorating circumstances. Coding this behavior under this node within NVivo involved recognizing any signs of spatial, geographic, operational or procedural disorientation. Situational awareness includes the full appreciation of not only the aircraft's physical position in space and time, but the correct procedures and the ability to plan appropriate responses to the real aircraft situation. Table 8 shows some of the most illustrative examples of Loss of Situational Awareness.

Table 8. Examples of Loss of Situational Awareness.

\begin{tabular}{cl}
\hline Accident Report & \multicolumn{1}{c}{ Examples } \\
\hline $04-04$ & $\begin{array}{l}\text { Investigation determined that pilots have generally had little exposure to, and therefore } \\
\text { may not fully understand, the effect of large rudder pedals inputs in normal flight or the } \\
\text { mechanism by which rudder deflections induce roll on a transport category airplane. }\end{array}$ \\
\hline 01-02 & $\begin{array}{l}\text { An unidentified voice in the cockpit stated, "a ... . we' are off course." In a post-accident } \\
\text { interview, the first officer stated that he thought the airplane was stabilized until about } \\
400 \text { feet above the field elevation, at which point the airplane drifted to the right. }\end{array}$ \\
\hline
\end{tabular}


Table 8. Cont.

\begin{tabular}{|c|c|}
\hline Accident Report & Examples \\
\hline $05-02$ & $\begin{array}{l}\text { A review of the first officer's medical record from his personal psychiatrist revealed that, } \\
\text { in July 2001, he began seeing the psychiatrist for treatment of various anxiety-related } \\
\text { symptoms. The psychiatrist prescribed alprazolam to treat the first officer condition. } \\
\text { Common side effects of alprazolam include drowsiness and light-headedness. }\end{array}$ \\
\hline $11-02$ & $\begin{array}{l}\text { Flight crew's failure to monitor and maintain a minimum safe airspeed while executing } \\
\text { an instrument approach in icing conditions, which resulted in an aerodynamic stall at } \\
\text { low altitude. }\end{array}$ \\
\hline $91-05$ & $\begin{array}{l}\text { About } \frac{1}{2} \text { min later, the first officer stated, "guess we turn here." When the captain } \\
\text { expressed some doubt about this left turn, the first officer replied, "Near as I can tell. } \\
\text { Man, I can't see out here." }\end{array}$ \\
\hline $91-05$ & $\begin{array}{l}\text { A lack of proper crew coordination, including a virtual reversal of roles by the DC } 9 \\
\text { pilots, which led to their failure to stop taxing their airplane and alert ground controller } \\
\text { of their positional uncertainty in a timely manner before and after intruding onto the } \\
\text { active runway. }\end{array}$ \\
\hline $93-02$ & $\begin{array}{l}\text { He believed that the snow had "all but stopped" and was more concerned about the } \\
\text { amount of vehicular traffic, such as sweepers and plows, than he was about the snowfall. }\end{array}$ \\
\hline 06-01 & $\begin{array}{l}\text { Captain asked, "what do you think?," and the first officer responded, "I can't see } \\
\text { [expletive]." About } 2 \mathrm{~s} \text { later, as the airplane continued to descend, the captain stated, } \\
\text { "yeah, oh there it is. Approach lights in sight." Almost immediately, the GPWS } \\
\text { annunciated "two hundred" feet. }\end{array}$ \\
\hline $97-01$ & $\begin{array}{l}\text { According to the first officer, the captain reached up to the overhead panel as the GPWS } \\
\text { was alerting. The captain did not recall doing this and stated that he had interpreted the } \\
\text { GPWS alerts as a high sink rate warning. The Captain decided to continue to land from } \\
\text { an unstable approach without realizing the gear was up and flaps were up. The result } \\
\text { was a wheels up landing at the Houston airport. }\end{array}$ \\
\hline $06-03$ & $\begin{array}{l}\text { About } 1 \text { min later, the first officer stated, "something's messed up with this thing," and, } \\
\text { at 0039:07, he asked "why is this thing?" At 0041:21, the first officer stated that the } \\
\text { control wheel felt "funny." He added, "feels like I need a lot of force. It is pushing to the } \\
\text { right for some reason. I don't know why...I don't know what's going on." The first officer } \\
\text { then repeated twice that it felt like he needed "a lot of force." The CVR did not record the } \\
\text { captain responding to any of these comments. }\end{array}$ \\
\hline $10-01$ & $\begin{array}{l}\text { The reason the captain did not recognize the impending onset of the stick shaker could } \\
\text { not be determined from the available evidence but that the first officer's tasks at the time } \\
\text { the low-speed cue was visible would have likely reduced opportunities for her timely } \\
\text { recognition of the impending event; the failure of both pilots to detect this situation was } \\
\text { the result of a significant breakdown in their monitoring responsibilities and workload } \\
\text { management. }\end{array}$ \\
\hline $06-03$ & $\begin{array}{l}\text { The flight crew did not monitor the fuel quantity gauges or respond properly to the } \\
\text { airplane's changing handling characteristics. }\end{array}$ \\
\hline $91-09$ & $\begin{array}{l}\text { Flight crew's failure to detect and remove ice contamination from the wings was a causal } \\
\text { factor in this accident. }\end{array}$ \\
\hline
\end{tabular}

Phrases such as doubt, positional uncertainty, failure to detect, I don't know why, I don't know what's going on and did not recall doing are all examples of not being aware. The tag cloud represented by Figure 8 shows that the most frequently-coded words during the analysis were captain, airplane, approach, first and officer. These words have also frequently appeared as the most common words with the previous behavioral traps. Once again, it seems as though it is during the approach and landing phase where crew confusion regarding the airplane status is mostly being exemplified. 


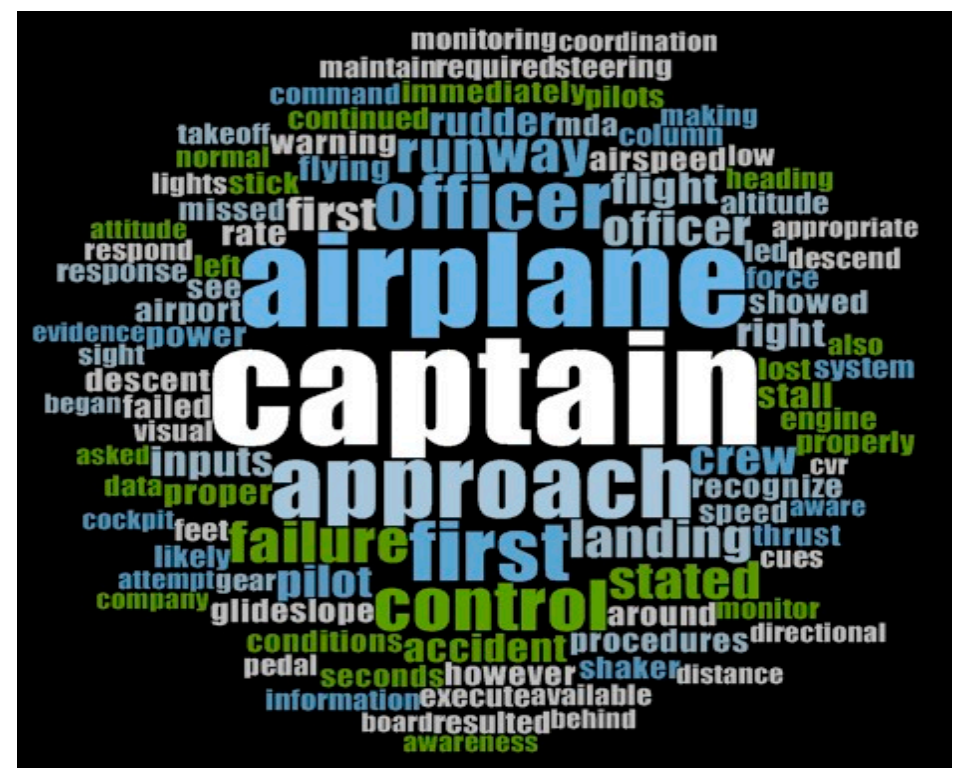

Figure 8. Word frequency tag cloud for Loss of Situational Awareness.

Flying Outside the Envelope can range from the pilot assuming an inappropriate level of performance capability of a particular aircraft, intentionally exceeding aircraft limits assuming there is a margin of safety built into the aircraft or an overestimation of the pilot's flying skills that causes the flight to exceed the aircraft's structural and/or aerodynamic limits. In any case, the pilot allows or causes the aircraft to exceed its design limitations. See Table 9 for the occurrences of this behavioral trap, which was found in seven (21\%) of 34 accidents.

Table 9. Examples of Flying Outside the Envelope.

\begin{tabular}{cl}
\hline Accident Report & \multicolumn{1}{c}{ Examples } \\
\hline $04-04$ & $\begin{array}{l}\text { The probable cause of this accident was the in-flight separation of the vertical stabilizer } \\
\text { as a result of the loads beyond ultimate design that were created by the first officer's } \\
\text { unnecessary and excessive rudder pedal inputs. }\end{array}$ \\
\hline $01-02$ & $\begin{array}{l}\text { Continuation of the approach to a landing when the company's max crosswind was } \\
\text { exceeded and use of reverse thrust greater than 1.3 engine per ratio after landing. }\end{array}$ \\
\hline $05-01$ & $\begin{array}{l}\text { The excessive vertical and lateral forces on the right main landing gear during the } \\
\text { landing exceeded those that the gear was designed to withstand and resulted in the } \\
\text { fracture of the outer cylinder and the collapse of the right main landing gear. }\end{array}$ \\
\hline $06-03$ & $\begin{array}{l}\text { The captain's calculations showed the airplane outside of acceptable weight and balance } \\
\text { limits. }\end{array}$ \\
\hline
\end{tabular}

Table 9 reveals that there were many ways that a crew exceeded airplane design limits. This was exemplified by excessive rudder inputs, operations beyond the company's maximum crosswind limit, too much landing force on only one main landing gear and operations past the acceptable weight and balance limitations. Figure 9 shows us the word frequency tag cloud for this behavioral trap. The most commonly-found words were airplane, landing, captain, accident, approach, company and exceeding. Because two of these accidents occurred during the approach and landing phase, it is not surprising to see both terms in the list of most frequently-used words. In order to operate outside of the envelope, a company or manufacturer limit must have been exceeded. Hence, the words company and exceeded. Finally, it should be no surprise that these actions all resulted in an accident. Therefore, the query also provided the word accident as one of the top words. 


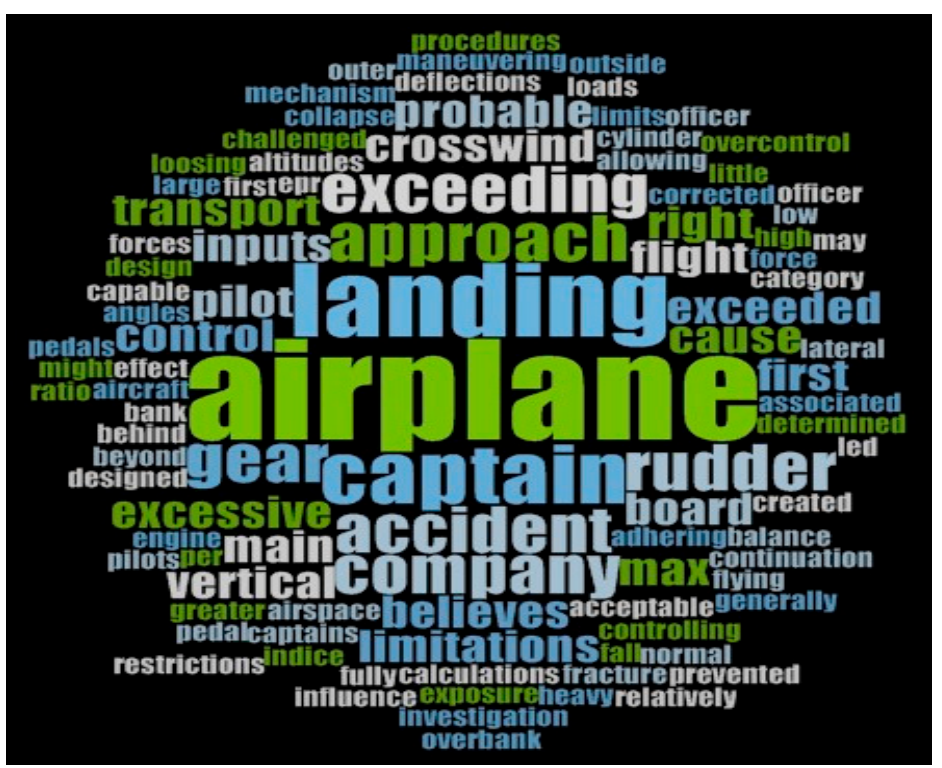

Figure 9. Tag cloud for Flying Outside the Envelope.

\subsection{Additional Contributing Factors Such as Airline Management, CRM Issues, and Fatigue}

During the analysis, the SMEs discovered that many accidents were also the result of factors outside of the five behavioral traps under study. These factors included airline management, CRM issues and fatigue. Airline management causes are shown in Table 10. CRM issues are shown in Table 11. Examples of fatigue are presented in Table 12. A word frequency query within NVivo explored these issues further. Thus, Figures 10-12 display the word frequency tag clouds for each contributing factor, respectively.

Passages such as "the airplane was dispatched to ANC with left engine thrust reverser inoperative, the company did not teach its pilots bounced landing recovery techniques, Maintenance personnel use of an inappropriate manual engine star procedure, and use the QRH instead of the manual" are all indications of airline management operational deficiencies that contributed to many airplane accidents. James Reason [21] created the term organizational accident to allude to those aviation mishaps that were caused by latent failures within the organization. These organizational errors when left alone and unattended to, may lead to a catastrophic event such as an accident.

The most commonly-used words found in the word frequency query for airline management issues were airplane, procedures, company and inspection. Many company management issues, such as lack of, or bad, procedures and inspections, may lead to the airplane experiencing a catastrophic event such as the aviation accident; hence the inclusion of the words company, procedures, inspections, and airplane.

The very existence of behavioral traps signals a breakdown in CRM. When crews fail to recognize, do not monitor, exchange flight controls abruptly, fail to communicate on their situation and are unable to manage their workload, a lack of CRM is present. In some of these passages, the reader may detect a sense of urgency or emotional intensification such as when expletives are used or when abnormal discussions are present.

The words most commonly coded within CRM issues were captain, first, officer, airplane and approach. Unsurprisingly, these words have come up again as the most frequently-used words. Given that CRM is an issue of team dynamics inside the cockpit, the words airplane, first, officer and captain were expected. The word approach, once again, might indicate a pattern of CRM breakdown in the busiest, and arguably most critical, phase of flight, that is the approach and landing stage. 
Table 10. Examples of airline management as a contributing factor.

\begin{tabular}{|c|c|}
\hline Accident Report & Examples \\
\hline $00-02$ & $\begin{array}{l}\text { According to flight plan and release documents, the airplane was dispatched to ANC [airport } \\
\text { code for Anchorage, Alaska] with left engine thrust reverser inoperative. }\end{array}$ \\
\hline $05-02$ & $\begin{array}{l}\text { Executive airline's manager of training and standards stated that, before the accident, the } \\
\text { company did not teach its pilots bounced landing recovery techniques. The manager also } \\
\text { stated that he would not want to conduct bounced landing recovery training in the simulator } \\
\text { because it was very difficult to demonstrate. }\end{array}$ \\
\hline 09-03 & $\begin{array}{l}\text { Maintenance personnel use of an inappropriate manual engine star procedure, which led to } \\
\text { the uncommanded opening of the left engine air turbine starter valve, and subsequent left } \\
\text { engine fire. }\end{array}$ \\
\hline $95-01$ & $\begin{array}{l}\text { The checklist deviations and other pilot procedural deficiencies noted by the FAA during a } \\
\text { special inspection, which included numerous en route inspections about one month before the } \\
\text { accident, suggest that the problems identified in this accident regarding improper checklist } \\
\text { procedures were systemic at COA [Continental Airlines]. If pilots fail to adhere to procedures } \\
\text { during en route inspections by FAA inspectors, they most likely behave in a similar manner } \\
\text { when no inspector is present. }\end{array}$ \\
\hline $96-07$ & $\begin{array}{l}\text { The first officer stated that when he and his classmates questioned the absence of the [manual], } \\
\text { the Flight Safety International simulator instructors informed them that ValuJet wanted them } \\
\text { to use the QRH [quick reference handbook] "like a Bible" for abnormal procedures. The first } \\
\text { officer indicated that he and his classmates stopped their first simulator session and called the } \\
\text { company to get an official determination as to what guidance they should use for abnormal } \\
\text { and emergency procedures during routine flight operations; he stated that ValuJet } \\
\text { management advised them to use the QRH instead of the manual. }\end{array}$ \\
\hline 91-09 & $\begin{array}{l}\text { The DC-9 Operations Manuals were basically developed by Ryan from the airplane's previous } \\
\text { owner's Operations Manuals, and certain purported Ryan practices were not incorporated } \\
\text { into them. The requirement to conduct an exterior inspection of the airplane at intermediate } \\
\text { stops was one of those practices not incorporated. In fact, the preflight inspection requirement } \\
\text { in the Ryan DC-9 manual clearly indicated that exterior inspections were required only on } \\
\text { originating flights or after the airplane had been left unattended. }\end{array}$ \\
\hline
\end{tabular}

Table 11. Examples of CRM issues as contributing factors.

\begin{tabular}{cl}
\hline Accident Report & \multicolumn{1}{c}{ Examples } \\
\hline 05-01 & $\begin{array}{l}\text { Proper CRM was not present. The captain never made a comment regarding the } \\
\text { deviations or helped the First Officer before landing. }\end{array}$ \\
\hline Th-02 & $\begin{array}{l}\text { The captain commented about the flap problem, neither crewmember discussed a } \\
\text { procedure or checklist to address it. The flight crew's poor communication and failure to } \\
\text { follow operating procedures regarding flap asymmetry, showed the lack of proper Crew } \\
\text { Resource Management and Negligence as a Flight Crew during the approach. }\end{array}$ \\
\hline 14-02 & $\begin{array}{l}\text { The captain changed the autopilot mode from the previously briefed profile approach to } \\
\text { vertical speed mode, initially setting the vertical descend rate to about 700 fpm, then } \\
\text { increasing it to 1000 fpm; however, he did not brief the first officer about the autopilot } \\
\text { mode change }\end{array}$ \\
\hline 91-05 & $\begin{array}{l}\text { A lack of proper crew coordination, including a virtual reversal of roles by the DC9 } \\
\text { pilots, which led to their failure to stop taxing their airplane and alert ground controller } \\
\text { of their positional uncertainty in a timely manner before and after intruding onto the } \\
\text { active runway. }\end{array}$ \\
\hline 98-03 & $\begin{array}{l}\text { The captain did not adequately manage his crew resources when he failed to call for } \\
\text { checklist or to monitor and facilitate the accomplishment of required checklist items. }\end{array}$ \\
\hline
\end{tabular}


Table 11. Cont.

\begin{tabular}{|c|c|}
\hline Accident Report & Examples \\
\hline $97-01$ & $\begin{array}{l}\text { The first officer told Safety Board investigators that his goal after recognizing that the } \\
\text { flaps were not extended was to get the captain to initiate a go-around. Thirty seconds } \\
\text { before touchdown, the first officer stated "want to take it around?" and the captain } \\
\text { replied "no that's alright, keep your speed up here about uh." When the captain denied } \\
\text { the first officer's request to go around and told him to keep his speed up, the first officer } \\
\text { did not challenge the captain's statement. He also did not question the captain to } \\
\text { determine his reason(s) for continuing the approach. The first officer stated that there } \\
\text { was no time for discussion with the captain because the approach was so fast. The first } \\
\text { officer's failure to question the captain's decision to continue the approach was } \\
\text { inconsistent with the CRM training he had received that emphasized the importance of } \\
\text { sharing doubts with other crewmembers and quickly resolving conflicts. }\end{array}$ \\
\hline $92-05$ & $\begin{array}{l}\text { The flight engineer brought to the captain's attention the airspeed deviation but the } \\
\text { captain never corrected; neither the first officer nor the flight engineer called for a } \\
\text { go-around. }\end{array}$ \\
\hline $95-03$ & $\begin{array}{l}\text { During the course of performing the missed approach procedure, the first officer acted, } \\
\text { without challenge, to a command from the captain to "down, push it down." }\end{array}$ \\
\hline $94-01$ & $\begin{array}{l}\text { The flight crew ignored the present weather conditions and continued the approach to } \\
\text { land even during the unestablished approach, the captain took the flight controls at the } \\
\text { last moment when it was too late to correct or execute a go around. }\end{array}$ \\
\hline $92-05$ & $\begin{array}{l}\text { Shortly thereafter, the cockpit voice recorder CVR revealed comments by the captain on } \\
\text { the first officer's flying technique, such as "If you're gonna fly that slow you gotta have } \\
\text { more flaps," and "[unintelligible words] still don't have enough flaps for this speed...add } \\
\text { power...you're not on the glidepath...bring it up to the glidepath," and "You're not even } \\
\text { on the [expletive] localizer at all." At } 0313 \text {, the captain stated "Okay, we're gonna have } \\
\text { to go around...cause we're not anywhere near the localizer ... anywhere near it." }\end{array}$ \\
\hline $93-04$ & $\begin{array}{l}\text { Inexplicably, the first officer reacted to the stick shaker by immediately deciding that the } \\
\text { captain should be flying and abandoning control of the airplane to the captain without } \\
\text { warning or proper coordination. }\end{array}$ \\
\hline $06-03$ & $\begin{array}{l}\text { About } 1 \text { min later, the first officer stated, "something's messed up with this thing," and, } \\
\text { at } 0039: 07 \text {, he asked "why is this thing?" At } 0041: 21 \text {, the first officer stated that the } \\
\text { control wheel felt "funny." He added, "feels like I need a lot of force. It is pushing to the } \\
\text { right for some reason. I don't know why...I don't know what's going on." The first officer } \\
\text { then repeated twice that it felt like he needed "a lot of force." The CVR did not record the } \\
\text { captain responding to any of these comments. }\end{array}$ \\
\hline $10-01$ & $\begin{array}{l}\text { The reason the captain did not recognize the impending onset of the stick shaker could } \\
\text { not be determined from the available evidence but that the first officer's tasks at the time } \\
\text { the low-speed cue was visible would have likely reduced opportunities for her timely } \\
\text { recognition of the impending event; the failure of both pilots to detect this situation was } \\
\text { the result of a significant breakdown in their monitoring responsibilities and workload } \\
\text { management. }\end{array}$ \\
\hline $92-05$ & $\begin{array}{l}\text { Failure of the crew to recognize and recover from an unusual attitude after experiencing } \\
\text { spatial disorientation or an attitude indicator failure during the second missed approach. }\end{array}$ \\
\hline $06-03$ & $\begin{array}{l}\text { The flight crew did not monitor the fuel quantity gauges or respond properly to the } \\
\text { airplane's changing handling characteristics. }\end{array}$ \\
\hline $91-09$ & $\begin{array}{l}\text { Flight crew's failure to detect and remove ice contamination from the wings was a causal } \\
\text { factor in this accident. }\end{array}$ \\
\hline
\end{tabular}

All these NTSB excerpts signal a lack of proper sleep or operations outside of a normal sleep schedule. Other signs of fatigue could be simple misspeaks, as when talking over the radio or discernable yawns on the CVR. According to the FAA [1], a fatigued aviator cannot perform at a level corresponding with the operational requirements, and the fatigue itself can be as incapacitating as drug use. 
Table 12. Examples of fatigue as a contributing factor.

\begin{tabular}{cl}
\hline Accident Report & \multicolumn{1}{c}{ Examples } \\
\hline \multirow{2}{*}{$06-01$} & $\begin{array}{l}\text { The pilots were flying their sixth flight of the day and had flown about } 6 \mathrm{~h} \text { and } 14 \mathrm{~min} \text { in } \\
14 \mathrm{~h} \text { and } 31 \text { min of duty time when the accident occurred. CVR recorded a yawn on the } \\
\text { first officer's channel. }\end{array}$ \\
\hline \multirow{2}{*}{$10-01$} & $\begin{array}{l}\text { Each pilot made an inappropriate decision to use the crew room to obtain rest before the } \\
\text { accident flight. }\end{array}$ \\
& $\begin{array}{l}\text { There were several obvious "misspeaks" by both pilots (drift vs. crab, and } 25 \text { degrees } \\
\text { flaps vs. 23 degrees flaps) that may have indicated some degree of fatigue. } \\
\text { Notwithstanding the fact that the crewmembers of flight } 805 \text { were air cargo operations } \\
\text { veterans and had adapted to these types of disrupted work/sleep schedules many times, } \\
\text { this experience did not make them immune to the possible adverse effects of fatigue or } \\
\text { their ability to function effectively. }\end{array}$ \\
& $\begin{array}{l}\text { The captain reported that he received only about } 1 \mathrm{~h} \text { of sleep during the night before the } \\
\text { accident and, as a result, asked the first officer to be the flying pilot for the flight. }\end{array}$ \\
\hline $08-01$ &
\end{tabular}

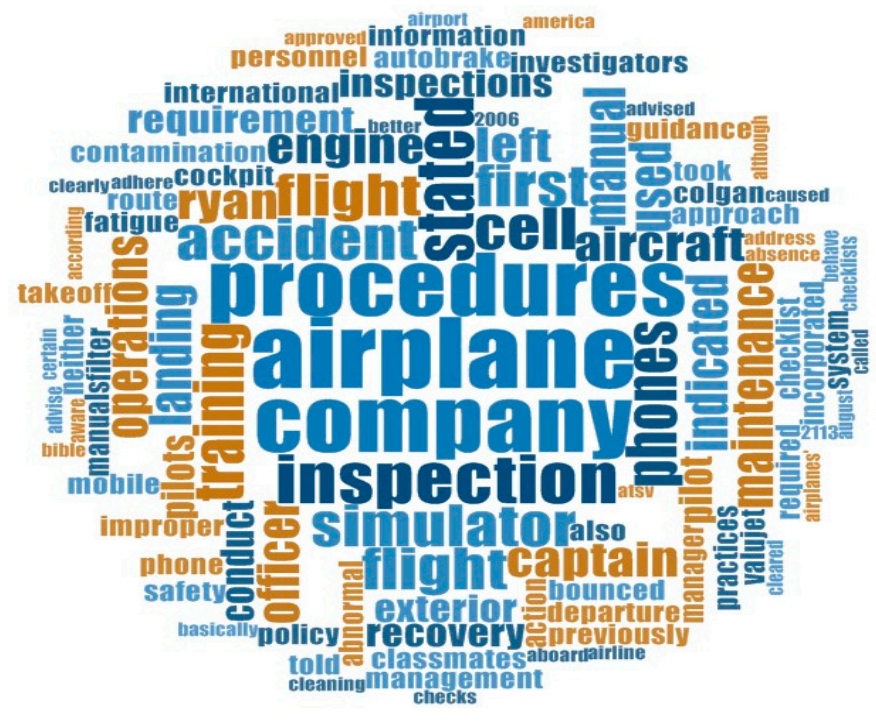

Figure 10. Tag cloud for airline management contributing factors.

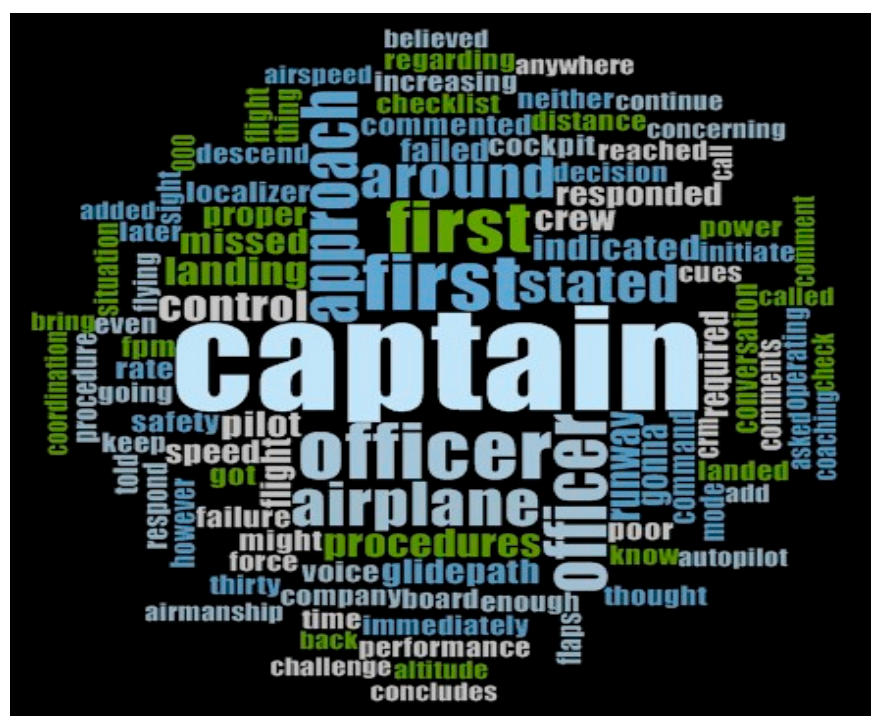

Figure 11. Word frequency tag cloud for CRM issues. 


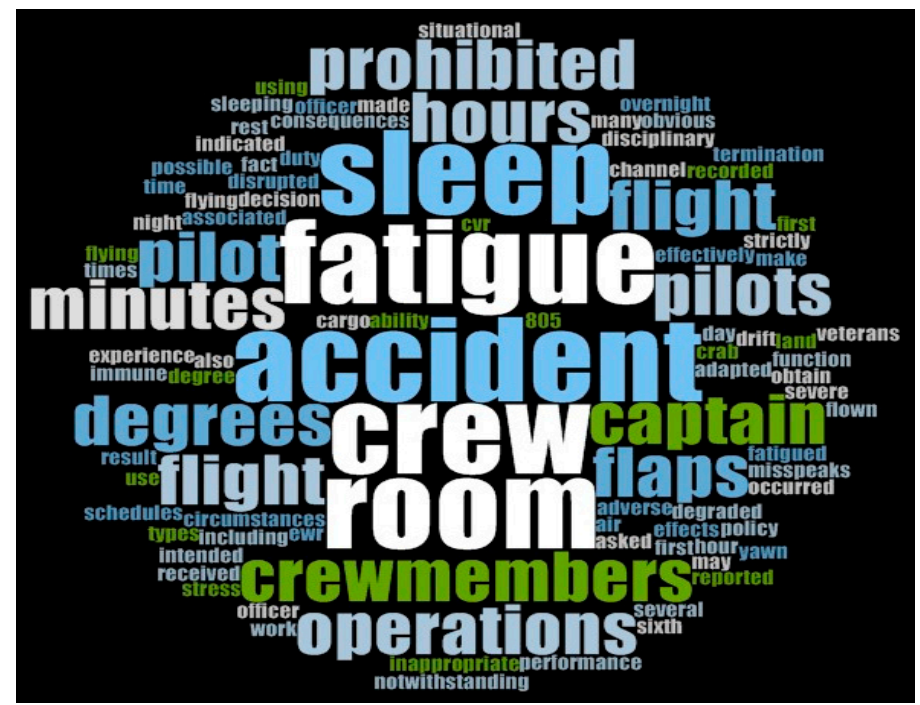

Figure 12. Tag cloud for fatigue as a contributing factor.

The most commonly-coded words within fatigue were accident, fatigue, sleep, crew and room. Some the excerpts from Table 12 clearly show pilots suffering from fatigue and using the crew room to sleep or get adequate rest.

\section{Discussion}

Neglect of Flight Planning, Preflight Inspections and Checklists was the most widespread behavioral trap. This unsafe behavior was identified in $79 \%$ of the accidents studied. Loss of Situational Awareness came in a close second place with representation in $74 \%$. Peer Pressure was found in $18 \%$ of accidents, while the traps of Get-There-Itis and Unauthorized Descent Below an IFR Altitude were both present in $15 \%$ of the accidents.

\subsection{Neglect of Flight Planning, Preflight Inspections, and Checklists}

A review of the NTSB excerpts presented in the Results Section confirms many prior discoveries in that pilots, even air carrier aviators, might have a general disregard for rules or procedures and underutilize many resources at their disposal [6,15-17]. The findings of this study also align with [18], where willful violations were present in 35\% of regular air carrier flights observed, and the study conducted by Velazquez, Peck and Sestak [19], where Neglect of Flight Planning, Preflight Inspections, and Checklists was the most dominant trap.

If airline flight operations are so highly scripted [6], why are pilots unwilling to follow rules and established procedures? An explanation is that Part 121 pilots may experience a phenomenon called habitual noncompliance [15]. Highly qualified pilots who routinely fly together under repetitive circumstances may constantly betray their own Flight Operations Manual (FOM) processes. The NTSB and Goglia [15] advocate the installation of cockpit cameras to help ensure that pilots conduct themselves under established protocols [16].

\subsection{Loss of Situational Awareness}

The leading behavioral trap in fatal accidents was Loss of Situational Awareness. This is not surprising because the concept involves more than knowledge of the aircraft's geographical or spatial position. It also comprises the pilot's consciousness of the different elements affecting the overall status of the aircraft. These elements include weather, aircraft condition, crewmember state and mission or flight progress. If passengers are being transported, they also form part of the expansive definition of situational awareness [4]. Thus, any sign of spatial, geographic, operational or procedural 
disorientation would be coded under Loss of Situational Awareness. As opposed to the previous behavioral trap of Neglect of Flight Planning, Preflight Inspections and Checklists under Loss of Situational Awareness, the crew may not be cognizant of danger. Sadly, this may explain it being the leading prevalence of behavioral traps under fatal accidents.

\subsection{Peer Pressure}

Human beings have a natural desire to conform to others, to be accepted [20]. As stated earlier, Peer Pressure can be verbal, or non-verbal, obvious or subtle, intentional or unintentional, and its origin may be personnel or organizational [20]. In all but one case examined during this study, it was the captain of the flight who was the source of Peer Pressure for the first officer. A look at all the word frequency queries associated with the behavioral traps studied revealed that the word captain is within the top five most commonly-found words. This finding suggests that first officers are automatically disengaging or suppressing their own arguments for the sake of acceptance. This lack of assertiveness is further explained in a following section. Finally, although there were instances of managerial factors that contributed to the accidents, no overwhelming evidence was found that airlines provided organizational pressure to crews of the ill-fated flights.

\subsection{Get-There-Itis}

As mentioned earlier, as the flight progresses, the pilots' desire to continue gets stronger $[6,20]$. This tendency was exemplified in Table 10 where four out of five cases of Get-There-Itis occurred during the approach and landing phase. This finding confirms what Dismukes et al. [6] called plan continuation bias, a failure of the crew to "discontinue an approach when it becomes inappropriate or dangerous to do so." Interestingly, the word frequency tag cloud for Get-There-Itis, and for five out of the six behavioral traps studied, suggests that behavioral traps occur mostly in the approach and landing phase of the flight because the words approach and/or landing appear as top common words. This is not surprising considering that the majority of aviation accidents, including commercial, occur during the approach and landing phase of flight.

\subsection{Unauthorized Descent below an IFR Altitude}

A look at Figure 9 reveals that the word MDA or Minimum Descent Altitude was among the most frequently found within the documented sources. This finding initiated a search back into the NTSB excerpts found in Table 11 to find out whether or not all instances of Descending Below an IFR Altitude were indeed associated with non-precision approaches or approaches where no vertical guidance is available. The conclusion was a resounding yes. All cases of this behavioral trap were associated with non-precision approaches. These types of instrument approaches add complexity to the approach and landing phase of the flight, more so if the approach was originally a precision approach, and due to technological difficulties, the crew was left with a different approach at the last minute.

\subsection{CRM Issues}

The third overall factor contributing to the accidents was lack of CRM practices. This finding is not surprising considering the most prevalent behavioral trap across all cases was Neglect of Flight Planning, Preflight Inspections, and Checklists. In addition, there was the presence of other CRM-rescinding traps such as Peer Pressure, Unauthorized Descent Below an IFR Altitude, Get-There-Itis and the additional discovered trap of Flying Outside the Envelope.

CRM is the epitome or ultimate expression of teamwork between flight crewmembers prior to, during and after a flight. Good CRM practices are predicated on the following checklists, SOPs, conducting good preflight action and engaging in proper flight planning to prepare for unexpected events during the flight. However, as seen throughout this study, crews are falling under habitual noncompliance, and first officers are demonstrating a lack of assertiveness. Broome [21] believes pilots are rejecting CRM. Is it time to refresh or revamp CRM training? 
Though CRM has evolved through many generations to the point that crews today are aware that the best strategy is to manage threats and errors, it looks as if CRM training lacks an important component called attitude management training. Attitude management is defined as "the ability to recognize hazardous attitudes in oneself and the willingness to modify them as necessary" [3]. Unfortunately, the FAA CRM training guidance [8] does not provide any direction on attitude management training, nor does it provide much information about hazardous attitudes, behavioral traps or the various cognitive biases with which pilots are confronted. The FAA has recently published a Notice of Proposed Rulemaking (NPRM) to increase airline pilot professionalism and ensure pilots adhere to SOPs. With this new NPRM, now would be a logical moment to define and introduce attitude management training as a formal component to CRM training.

Line-Oriented Flight Training (LOFT) has been the preferred CRM training method for years. However, the results of this study confirm many findings [6,22] suggesting that this scenario-based training tool may not be applied effectively and continuously. Dismukes et al. [6] cites inadequate knowledge or experience provided by training and/or guidance as a factor in $37 \%$ of NTSB accidents between 1991 and 2001. In other words, pilots were not given adequate instruction about problems known by some of the sectors of the industry to exist or, "found themselves in challenging situations for which they had received training, but the experience received from that training was of inadequate fidelity to the actual situation, inadequately detailed, or incomplete" [6].

\section{Conclusions and Recommendations}

\subsection{Conclusions}

This paper accomplished many firsts and contributed considerably to the understanding of how negative behaviors (specifically behavioral traps) are present in airline operations. No published study had tackled behavioral traps in air carrier operations until now. Secondly, this paper revises Jeppesen's [11] categorization of behavioral traps among GA, instrument-rated and commercial pilots. For example, it was discovered that the behavioral trap of Flying Outside the Envelope is not exclusive to GA pilots; airline pilots also exceed airplane operational tolerances. Finally, the study also makes public how flight crews might be practicing CRM and tells the story of the captains' preeminence. A look at all the word frequency queries associated with the behavioral traps revealed that the word captain is within the top five most commonly-found words. Could it be that captains are overpowering their fellow first officers? Are today's captains still being overly dominant? If so, how effective is CRM if it is evident that first officers are automatically disengaging or suppressing their own arguments for the sake of acceptance?

As indicated earlier, Flying Outside the Envelope should be included in the commercial category of behavioral traps [11] among commercial, instrument-rated and GA pilots due to its presence in $21 \%$ of accidents analyzed. With the exception of Peer Pressure, all other behavioral traps mainly occur in the approach and landing phase of flight. This finding coincides with the phase of flight responsible for the majority of commercial aviation accidents. Finally, Unauthorized Descent Below an IFR Altitude was completely related to non-precision approaches or instrument approaches without vertical guidance in the approach design. These instrument approaches add a level of complexity to the operation as opposed to those precision approaches where an electronic vertical guidance is available.

\subsection{Recommendations}

\subsubsection{Recommendations for Further Study}

Because this study focused on U.S. 14 CFR Part 121 crew-related accidents, any future studies can focus on Part 135 commercial and air taxi operators. In addition, while the information contained in the National Aeronautics and Space Administration's ASRS accounts is self-reported by the pilots, 
valuable information can be retrieved from these incident reports to continue to understand unsafe pilot behaviors, whether they are defined as hazardous attitudes or behavioral traps.

Because Neglect of Flight Planning, Preflight Inspections, and Checklists was the top behavioral trap, additional research should focus on the reasons for customary noncompliance and pilot motivation. While the NTSB and Goglia [15] are advocating for cockpit cameras to be installed in air carrier operations, perhaps a better approach would be to scientifically review the flight data recorders. This assessment should be routinely accomplished by airlines in a non-punitive way [16].

\subsubsection{Recommendations for Industry}

The creation of CRM and alike programs does not always guarantee the absence of unsafe pilot behaviors [23-27]. However, effective crew performance depends on both technical proficiency and interpersonal skills. One of the main objectives behind the FAA's CRM training has always been to focus on crew member attitude and effectual teamwork. Because the FAA believes attitudes can be changed or modified through training [1], from the standpoint of accident prevention, education and training focused on the top behavioral traps would likely prove to have the highest payoff. This recommendation is especially true considering that Neglect of Flight Planning, Preflight Inspections and Checklists is the prevailing trap. Additional focus should be placed on: (1) the captain's authority and ability to identify and mediate unsafe behaviors; (2) the first officer's ability to be assertive and combat Peer Pressure; and (3) the approach and landing phase. The lack of first officer assertiveness and preeminence of the captains should be addressed in training and even investigated in future studies. This former action could be done through cognitive debiasing training and/or scenario-based training during LOFT sessions where additional focus is on the interpersonal skills of flight crewmembers.

Many behavioral traps exist in airline operation. The understanding of pilot attitudes and their role in team dynamics or impact on CRM requires further study. Finally, attitude management training is recommended as an added component in CRM training.

Acknowledgments: The author of this research project wishes to express gratitude to the following airline transport pilots who contributed their expertise to the data collection portion of this study. These individuals were: Kevin Roman, Oswart Mora, Omar Carle, and Pablo Ortiz.

Conflicts of Interest: The author declares no conflict of interest.

\section{References}

1. Federal Aviation Administration (FAA). Risk Management Handbook; Government Printing Office: Washington, DC, USA, 2009.

2. Federal Aviation Administration (FAA). Aeronautical Decision Making (Advisory Circular 60-22); Government Printing Office: Washington, DC, USA, 1991.

3. Sanderson, J. Private Pilot; Englewood, CO, USA, 2013.

4. Federal Aviation Administration (FAA). Aviation Instructor's Handbook; Government Printing Office: Washington, DC, USA, 2008.

5. Murata, A.; Nakamura, T.; Karwowski, W. Influence of Cognitive Biases in Distorting Decision Making and Leading to Critical Unfavorable Incidents. Safety 2015, 1, 44-58. [CrossRef]

6. Dismukes, R.K.; Berman, B.A.; Loukopoulos, L.D. The Limits of Expertise: Rethinking Pilot Error and the Causes of Airline Accidents; Ashgate Publishing Limited: Aldershot, UK, 2007.

7. Block, E.E.; Sabin, E.J.; Patankar, M.S. The structure of safety climate for accident free flight crews. Int. J. Appl. Aviat. Stud. 2007, 7, 46-59.

8. Federal Aviation Administration (FAA). Crew Resource Management Training (Advisory Circular AC 120-51e); Government Printing Office: Washington, DC, USA, 2004.

9. Helmreich, R.L.; Merritt, A.C.; Wilhelm, J.A. The evolution of crew resource management training in commercial aviation. Int. J. Aviat. Psychol. 1999, 9, 19-32. [CrossRef] [PubMed] 
10. Velazquez, J.; Bier, N. SMS and CRM: Parallels and opposites in their evolution. J. Aviat./Aerosp. Educ. Res. 2015, 24, 55-78. [CrossRef]

11. Jeppesen. Flight Instructor; JeppDirect: Englewood, CO, USA, 2014.

12. Bazeley, P. Qualitative Data Analysis: Practical Strategies; Sage: Thousand Oaks, CA, USA, 2013.

13. Lincoln, Y.S.; Guba, E.G. Naturalistic Inquiry; Sage: Beverly Hills, CA, USA, 1985.

14. Creswell, J.W. Educational Research: Planning, Conducting, and Evaluating Quantitative and Qualitative Research; Pearson Education, Inc.: Upper Saddle River, NJ, USA, 2005.

15. Goglia, J. Torqued: Is Gulfstream IV Crash Corporate Aviation's Wakeup Call? Available online: http:/ / www.ainonline.com/aviation-news/blogs/torqued-gulfstream-iv-crash-corporate-aviationswakeup-call (accessed on 1 December 2015).

16. Rapp, R. Bedford and the Normalization of Deviance. Available online: http://www.rapp.org/archives / 2015/12/normalization-of-deviance/ (accessed on 12 December 2015).

17. Veillette, P.R. Watching and waning. Bus. Commer. Aviat. 2006, 98, 60-63.

18. Klinect, J.R.; Wilhelm, J.A.; Helmreich, R.L. Threat and error management: Data from line operations safety audits (LOSA). In Proceedings of the 10th International Symposium on Aviation Psychology; The Ohio State University: Columbus, OH, USA, 2001.

19. Velazquez, J.; Peck, A.G.; Sestak, T. Behavioral traps in crew-related aviation accidents. In Proceedings of the 18th International Symposium on Aviation Psychology; Wright State University: Dayton, OH, USA, May 2015; pp. 372-377.

20. Kern, T. Flight Discipline; McGraw-Hill Professional: Columbus, OH, USA, 1998.

21. Broome, D.P. Accident reduction through crew resource management. J. Aviat./Aeros. Educ. Res. 2011, 20, 13-21. [CrossRef]

22. Wagener, F.; Ison, D.C. Crew resource management application in commercial aviation. J. Aviat. Technol. Eng. 2014, 3, 2-13. [CrossRef]

23. Cook, J.S. Analysis of Hazardous Pilot Behaviors and Causal Factors in Part 121 and Part 135 Aircraft Accidents and Incidents. Master's Thesis, Retrieved from ProQuest Dissertations and Theses database, (UMI No. 1409570). Arizona State University, Tempe, AZ, USA, 2002.

24. Mosier, K.L.; Fischer, U.; Cunningham, K.; Munc, A.; Reich, K.; Tomko, L.; Orasanu, J. Aviation decision making issues and outcomes: Evidence from ASRS and NTSB reports. In Proceedings of the Human Factors and Ergonomics Society Annual Meeting; Sage: Los Angeles, CA, USA, October 2012; pp. 1794-1798. [CrossRef]

25. Shappell, S.; Detwiler, C.; Holcomb, K.; Hackworth, C.; Boquet, A.; Wiegmann, D.A. Human error and commercial aviation accidents: An analysis using the human factors and classification system. Hum. Factors J. Hum. Factors Ergon. Soc. 2007, 49, 227-242. [CrossRef] [PubMed]

26. Wetmore, M.; Lu, C. The effects of hazardous attitudes on crew resource management skills. Int. J. Appl. Aviat. Stud. 2006, 6, 165-182.

27. Reason, J. Human Error; Cambridge University Press: Cambridge, UK, 1990.

(C) 2018 by the author. Licensee MDPI, Basel, Switzerland. This article is an open access article distributed under the terms and conditions of the Creative Commons Attribution (CC BY) license (http://creativecommons.org/licenses/by/4.0/). 